\title{
Dicarboxylic acids, oxoacids, benzoic acid, $\alpha$-dicarbonyls, WSOC, $O C$, and ions in spring aerosols from Okinawa Island in the western North Pacific Rim: size distributions and formation processes
}

\author{
Dhananjay K. Deshmukh ${ }^{1, a}$, Kimitaka Kawamura ${ }^{1, a}$, Manuel Lazaar ${ }^{1,2}$, Bhagawati Kunwar ${ }^{1}$, and \\ Suresh K. R. Boreddy ${ }^{1}$ \\ ${ }^{1}$ Institute of Low Temperature Science, Hokkaido University, Sapporo 060-0819, Japan \\ ${ }^{2}$ Ecole National Supérieure de Chimie de Rennes (ENSCR), Rennes 35708, France \\ a now at: Chubu Institute for Advanced Studies, Chubu University, Kasugai 487-8501, Japan
}

Correspondence to: Kimitaka Kawamura (kawamura@lowtem.hokudai.ac.jp)

Received: 23 July 2015 - Published in Atmos. Chem. Phys. Discuss.: 30 September 2015

Revised: 7 April 2016 - Accepted: 13 April 2016 - Published: 27 April 2016

\begin{abstract}
Size-segregated aerosols (nine stages from $<0.43$ to $>11.3 \mu \mathrm{m}$ in diameter) were collected at Cape Hedo, Okinawa, in spring 2008 and analyzed for water-soluble diacids $\left(\mathrm{C}_{2}-\mathrm{C}_{12}\right)$, $\omega$-oxoacids $\left(\omega \mathrm{C}_{2}-\omega \mathrm{C}_{9}\right)$, pyruvic acid, benzoic acid, and $\alpha$-dicarbonyls $\left(\mathrm{C}_{2}-\mathrm{C}_{3}\right)$ as well as water-soluble organic carbon (WSOC), organic carbon (OC), and major ions $\left(\mathrm{Na}^{+}, \mathrm{NH}_{4}^{+}, \mathrm{K}^{+}, \mathrm{Mg}^{2+}, \mathrm{Ca}^{2+}, \mathrm{Cl}^{-}, \mathrm{NO}_{3}^{-}, \mathrm{SO}_{4}^{2-}\right.$, and $\left.\mathrm{MSA}^{-}\right)$. In all the size-segregated aerosols, oxalic acid $\left(\mathrm{C}_{2}\right)$ was found to be the most abundant species, followed by malonic and succinic acids, whereas glyoxylic acid $\left(\omega \mathrm{C}_{2}\right)$ was the dominant oxoacid and glyoxal (Gly) was more abundant than methylglyoxal. Diacids $\left(\mathrm{C}_{2}-\mathrm{C}_{5}\right), \omega \mathrm{C}_{2}$, and Gly as well as WSOC and OC peaked at fine mode $(0.65-1.1 \mu \mathrm{m})$ whereas azelaic $\left(\mathrm{C}_{9}\right)$ and 9 -oxononanoic $\left(\omega \mathrm{C}_{9}\right)$ acids peaked at coarse mode $(3.3-4.7 \mu \mathrm{m})$. Sulfate and ammonium were enriched in fine mode, whereas sodium and chloride were in coarse mode. Strong correlations of $\mathrm{C}_{2}-\mathrm{C}_{5}$ diacids, $\omega \mathrm{C}_{2}$ and Gly with sulfate were observed in fine mode $(r=0.86-$ 0.99 ), indicating a commonality in their secondary formation. Their significant correlations with liquid water content in fine mode ( $r=0.82-0.95)$ further suggest an importance of the aqueous-phase production in Okinawa aerosols. They may also have been directly emitted from biomass burning in fine mode as supported by strong correlations with potassium $(r=0.85-0.96)$, which is a tracer of biomass burning. Bimodal size distributions of longer-chain diacid $\left(\mathrm{C}_{9}\right)$ and oxoacid $\left(\omega \mathrm{C}_{9}\right)$ with a major peak in the coarse mode suggest that they were emitted from the sea surface microlayers
\end{abstract}

and/or produced by heterogeneous oxidation of biogenic unsaturated fatty acids on sea salt particles.

\section{Introduction}

Tropospheric aerosol is an important environmental issue because it dramatically reduces the visibility (Jacobson et al., 2000; Kanakidou et al., 2005), affects the radiative forcing of climate (Seinfeld and Pandis, 1998), and causes a negative impact on human health (Pope and Dockery, 2006). All of these effects strongly depend on the abundances of aerosols and their chemical and physical properties in different sizes. Particles with diameters of $0.1-1.0 \mu \mathrm{m}$ are very active in scattering and absorbing incoming solar radiation and have a direct impact on climate (Ramanathan et al., 2001; Seinfeld and Pankow, 2003). The knowledge of size distributions of chemical components is thus essential to better understand their potential contributions to climate change and pollution control. Their size distribution also provides evidence for the sources and formation pathways of atmospheric particles.

The emission sources and multiple secondary formation pathways of organic aerosols are not well understood. Organic compounds account for up to $70 \%$ of fine aerosol mass and potentially control the physicochemical properties of aerosol particles (Davidson et al., 2005; Kanakidou et al., 2005). Low-molecular-weight diacids are one of the most abundant organic compound classes in the at- 
mosphere (Kawamura and Ikushima, 1993; Kawamura et al., 1996; Kawamura and Bikkina, 2016). They are primarily derived from incomplete combustion of fossil fuel and biomass burning (Kawamura and Kaplan, 1987; Falkovich et al., 2005), and secondarily produced in the atmosphere via photooxidation of unsaturated fatty acids and volatile organic compounds (VOCs) from biogenic and anthropogenic sources (Kawamura and Gagosian, 1987; Kawamura et al., 1996; Sempéré and Kawamura, 2003). The ability of organic aerosols to act as cloud condensation nuclei seems to be closely related to their mass-based size distributions (Pradeep Kumar et al., 2003; Ervens et al., 2007).

The increasing atmospheric burden of organic aerosols is associated with natural and anthropogenic emissions in the continental regions. Organic aerosols are eventually transported to the oceanic regions. Rapid industrialization in East Asia is expected to have an important impact on global atmospheric chemistry over the next decades (Wang et al., 2013; Tao et al., 2013; Bian et al., 2014). Large amounts of coal and biomass burning in East Asia add more anthropogenic aerosols which alter the aerosol chemical composition in the remote Pacific atmosphere (Mochida et al., 2007; Miyazaki et al., 2010; Agarwal et al., 2010; Wang et al., 2011; Engling et al., 2013). Water-soluble diacids and related compounds as well as major ions have previously been studied for their size distributions in remote marine aerosols (Kawamura et al., 2007: Mochida et al., 2007; Miyazaki et al., 2010), whereas their size-segregated characteristics have not been studied in the western North Pacific Rim.

We collected size-segregated aerosol samples with nine size ranges in spring 2008 in Cape Hedo, Okinawa, in the western North Pacific Rim. Cape Hedo is located on the northern edge of Okinawa Island and can serve as a suitable site for the observation of atmospheric transport of East Asian aerosols with insignificant interference from local emission sources (Takami et al., 2007). The samples were analyzed for dicarboxylic acids $\left(\mathrm{C}_{2}-\mathrm{C}_{12}\right)$ and related compounds such as $\omega$-oxoacids $\left(\omega \mathrm{C}_{2}-\omega \mathrm{C}_{9}\right)$, pyruvic acid $\left(\mathrm{C}_{3}\right)$, and $\alpha$-dicarbonyls $\left(\mathrm{C}_{2}-\mathrm{C}_{3}\right)$ to better understand the sources and processing of water-soluble organic compounds at this marine receptor site. Size-segregated samples were also analyzed for water-soluble organic carbon (WSOC), organic carbon (OC), and major inorganic ions. The role of liquid water content of aerosol in the size distribution of diacids and related compounds is discussed. The potential factors responsible for their size distributions are also discussed.

\section{Materials and method}

\subsection{Site description and aerosol collection}

The geographical location of Okinawa Island $\left(26.87^{\circ} \mathrm{N}\right.$ and $128.25^{\circ} \mathrm{E}$ ) and its surroundings in East Asia are shown in Fig. 1. Okinawa is located in the outflow region of con-

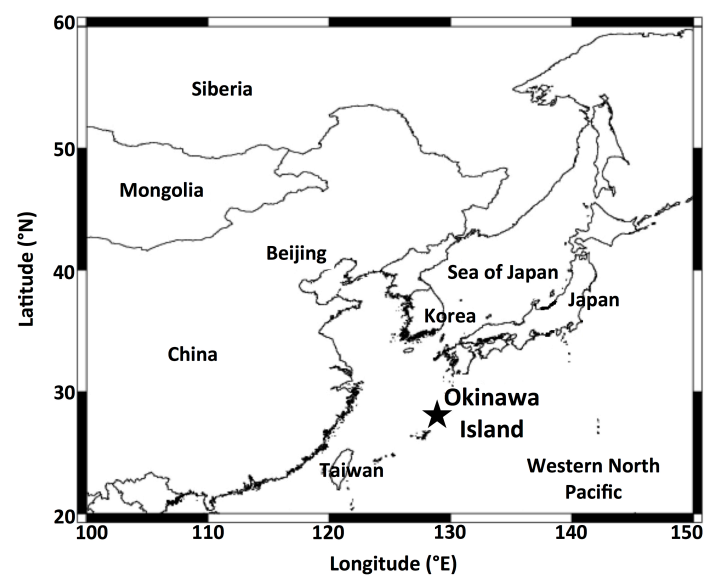

Figure 1. A map of East Asia with the location of Okinawa Island $\left(26.87^{\circ} \mathrm{N}\right.$ and $\left.128.25^{\circ} \mathrm{E}\right)$ and Asian countries.

tinental aerosols and on the pathways to the Pacific. Cape Hedo has been used as a supersite of the Atmospheric Brown Clouds project to study the atmospheric transport of Chinese aerosols and their chemical transformation during long-range transport from East Asia (Takiguchi et al., 2008; Kunwar and Kawamura, 2014). The sampling site at Cape Hedo is about $60 \mathrm{~m}$ a.s.l.

Size-segregated aerosol samples were collected at Cape Hedo Atmosphere and Aerosol Monitoring Station (CHAAMS) from 18 March to 13 April 2008. This period was characterized by westerly wind in the lower troposphere, which is the principal process responsible for the transport of both fossil fuel combustion and biomass burning aerosols in East Asia to the western North Pacific. 9-Stage Andersen middle volume impactor (Tokyo Dylec Company, Japan; $100 \mathrm{~L} \mathrm{~min}^{-1}$ ) was used for the collection of size-segregated samples. The sampler was equipped with quartz fiber filters (QFFs, $80 \mathrm{~mm}$ in diameter) that were precombusted at $450{ }^{\circ} \mathrm{C}$ for $6 \mathrm{~h}$ in a furnace to eliminate the adsorbed organic compounds. A total of five sets (OKI-1 to OKI-5) of size-segregated aerosol samples were collected. Each sample set consists of nine filters for the sizes of $<0.43,0.43-0.65$, $0.65-1.1,1.1-2.1,2.1-3.3,3.3-4.7,4.7-7.0,7.0-11.3$, and $>11.3 \mu \mathrm{m}$. The filter was placed in a preheated $50 \mathrm{~mL}$ glass vial with a Teflon-lined screw cap and stored in a freezer at the station. The samples were stored in darkness at $-20^{\circ} \mathrm{C}$ prior to analysis in Sapporo. One set of field blanks was collected by placing a precombusted QFF into the sampler for $30 \mathrm{~s}$ without sucking air before installing the real QFF.

\subsection{Analytical procedures}

Diacids and related compounds were determined by the method of Kawamura and Ikushima (1993), and Kawamura (1993). Aliquot of the filters was extracted with organic-free ultrapure water (specific resistivity $>18.2 \mathrm{M} \Omega \mathrm{cm}$ ) under ultrasonication. The extracts were 
passed through a glass column packed with quartz wool to remove insoluble particles and filter debris. The extracts were concentrated using a rotary evaporator under vacuum and derivatized to dibutyl esters and dibutoxy acetals with $14 \%$ $\mathrm{BF}_{3}$ in $n$-butanol at $100^{\circ} \mathrm{C}$. Acetonitrile and $n$-hexane were added into the derivatized sample and washed with organicfree pure water. The hexane layer was further concentrated using a rotary evaporator under vacuum and dried to almost dryness by $\mathrm{N}_{2}$ blowdown and dissolved in $100 \mu \mathrm{L}$ of $n$-hexane. $2 \mu \mathrm{L}$ of the sample was injected into a capillary gas chromatograph (GC) (Hewlett-Packard HP6890) equipped with a flame ionization detector. Authentic diacid dibutyl esters were used as external standards for the peak identification and quantification. Identifications of diacids and related compounds were confirmed by GC-mass spectrometry. Recoveries of authentic standards spiked to a precombusted QFF were $85 \%$ for oxalic acid $\left(\mathrm{C}_{2}\right)$ and more than $90 \%$ for malonic to adipic $\left(\mathrm{C}_{3}-\mathrm{C}_{6}\right)$ acids. The detection limits of diacids and related compounds were ca. $0.002 \mathrm{ng} \mathrm{m}^{-3}$. The analytical errors in duplicate analyses are within $10 \%$ for major species.

To measure water-soluble organic carbon (WSOC), a punch of $20 \mathrm{~mm}$ diameter of each QFF was extracted with organic-free ultrapure water in a $50 \mathrm{~mL}$ glass vial with a Teflon-lined screw cap under ultrasonication for $15 \mathrm{~min}$. The water extracts were subsequently passed through a syringe filter (Millex-GV, Millipore; diameter of $0.22 \mu \mathrm{m}$ ). The extract was first acidified with $1.2 \mathrm{M} \mathrm{HCl}$ and purged with pure air in order to remove dissolve inorganic carbon and then WSOC was measured using a total organic carbon (TOC) analyzer (Shimadzu TOC- $\mathrm{V}_{\mathrm{CSH}}$ ) (Miyazaki et al., 2011). External calibration was performed using potassium hydrogen phthalate before analysis of WSOC. The sample was measured three times and the average value was used for the calculation of WSOC concentrations. The analytical error in the triplicate analysis was $5 \%$ with a detection limit of $0.1 \mu \mathrm{gC} \mathrm{m} \mathrm{m}^{-3}$.

Organic and elemental carbon (OC and EC) was determined using a Sunset Lab carbon analyzer following the Interagency Monitoring of Protected Visual Environments (IMPROVE) thermal evolution protocol as described by $\mathrm{H}$. Wang et al. (2005). A filter disc of $1.5 \mathrm{~cm}^{2}$ was placed in a quartz tube inside the thermal desorption chamber of the analyzer and then stepwise heating was applied. Helium (He) gas was applied in the first ramp and was switched to mixture of $\mathrm{He} / \mathrm{O}_{2}$ in the second ramp. The evolved $\mathrm{CO}_{2}$ during the oxidation at each temperature step was measured with a non-dispersive infrared detector system. The detection limits of OC and $\mathrm{EC}$ were ca. 0.05 and $0.02 \mu \mathrm{gC} \mathrm{m}{ }^{-3}$, respectively. The analytical errors in the triplicate analysis of the filter sample were estimated to be 5\% for OC and EC. EC was detected only in fine fractions. The concentration of total carbon (TC) was calculated by summing the concentrations of $\mathrm{OC}$ and $\mathrm{EC}$ in each size fraction.

For the determination of major ions, a punch of $20 \mathrm{~mm}$ diameter of each filter was extracted with organic-free ul- trapure water under ultrasonication. These extracts were filtered through a disc filter (Millex-GV, Millipore; diameter of $0.22 \mu \mathrm{m}$ ) and injected into an ion chromatograph (Compact IC 761; Metrohm, Switzerland) for measuring $\mathrm{MSA}^{-}, \mathrm{Cl}^{-}$, $\mathrm{SO}_{4}^{2-}, \mathrm{NO}_{3}^{-}, \mathrm{Na}^{+}, \mathrm{NH}_{4}^{+}, \mathrm{K}^{+}, \mathrm{Ca}^{2+}$, and $\mathrm{Mg}^{2+}$ (Boreddy and Kawamura, 2015). Anions were separated on a SI-90 4E Shodex column (Showa Denko; Tokyo, Japan) using a mixture of $1.8 \mathrm{mM} \mathrm{Na}_{2} \mathrm{CO}_{3}$ and $1.7 \mathrm{mM} \mathrm{NaHCO}_{3}$ solution at a flow rate of $1.2 \mathrm{~mL} \mathrm{~min}^{-1}$ as an eluent and $40 \mathrm{mM} \mathrm{H}_{2} \mathrm{SO}_{4}$ for a suppressor. A Metrosep C2-150 Metrohm column was used for cation analysis using a mixture of $4 \mathrm{mM}$ tartaric acid and $1 \mathrm{mM}$ dipicolinic acid solution as an eluent at a flow rate of $1.0 \mathrm{~mL} \mathrm{~min}^{-1}$. The injected loop volume was $200 \mu \mathrm{L}$. The detection limits for anions and cations were ca. $0.1 \mathrm{ng} \mathrm{m}^{-3}$. The analytical error in duplicate analysis was about $10 \%$.

Field blanks were extracted and analyzed like the real samples. However, blank levels were $0.1-5 \%$ of real samples. The reported concentrations of organic and inorganic species were corrected for the field blanks. All the chemicals including authentic standards were purchased from Wako Pure Chemical Co. (Japan), except for $14 \% \mathrm{BF}_{3} / n$-butanol (Sigma-Aldrich, USA).

\subsection{Backward air mass trajectories and meteorology}

The backward trajectories of air masses were computed for the sampling period using the Hybrid Single-Particle Lagrangian Integrated Trajectory (HYSPLIT) model 4.0 developed by the National Oceanic and Atmospheric Administration (NOAA) Air Resources Laboratory (ARL) (Draxler and Rolph, 2013). The 7-day trajectories at $500 \mathrm{~m}$ above the ground level for the samples collected on Okinawa are shown in Fig. 2. Typical air mass trajectories corresponding to 09:00 UTC for the samples collected on Okinawa are shown in Fig. S1 in the Supplement.

Meteorological data including ambient temperature, relative humidity, and wind speed for each sample period were obtained from Japan Meteorological Agency (http://www. jma.go.jp). During our campaign, ambient temperature, relative humidity, and wind speed ranged from 11.9 to $26.6^{\circ} \mathrm{C}$ (ave. $20.0 \pm 2.6^{\circ} \mathrm{C}$ ), 43.0 to $91.0 \%$ (ave. $70.0 \pm 12.0 \%$ ), and 0.10 to $10.2 \mathrm{~m} \mathrm{~s}^{-1}$ (ave. $3.73 \pm 1.99 \mathrm{~m} \mathrm{~s}^{-1}$ ), respectively. The 7-day trajectories along with the meteorological data, including precipitation and downward solar radiation flux, are shown in Fig. S2.

\subsection{Estimation of liquid water content (LWC) of aerosol}

LWC of aerosol was calculated for the size-segregated samples collected on Okinawa Island using the ISORROPIA II model (Fountoukis and Nenes, 2007). ISORROPIA II is a computationally efficient and rigorous thermodynamic equilibrium model that exhibits robust and rapid convergence under all aerosol types with high computational speed 


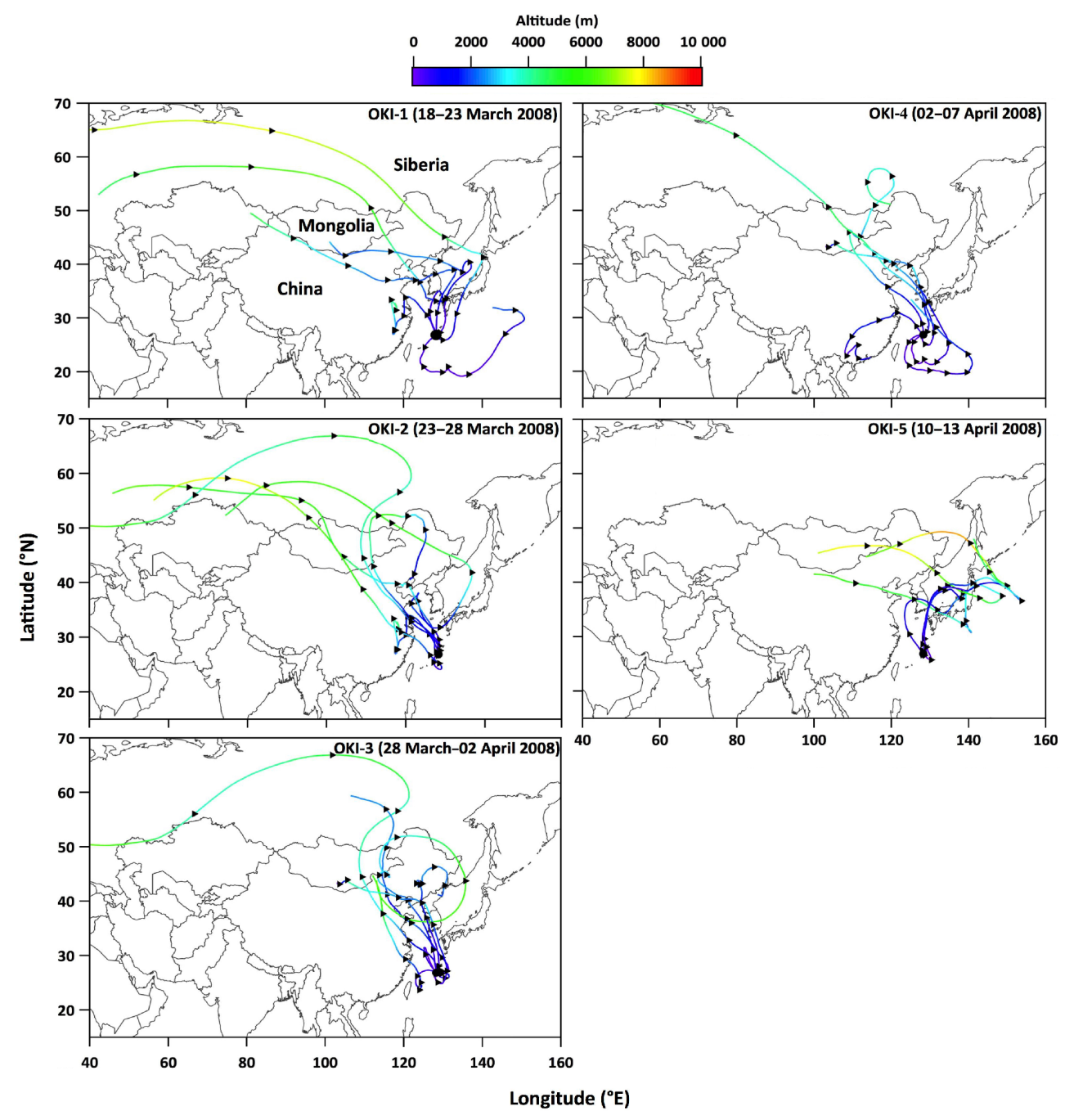

Figure 2. Seven-day backward air mass trajectories (NOAA HYSPLIT) at $500 \mathrm{~m}$ a.g.1. (09:00 UTC) for the aerosol samples (OKI-1 to OKI5) collected on Okinawa Island. The dates given in each panel are the starting and ending times of the collection of aerosol samples on Okinawa Island. The color scale shows the altitude of the air parcel.

(Nenes et al., 1998). ISORROPIA II implies the ZdanovskiiStokes-Robinson equation and treats only the thermodynamics of $\mathrm{K}^{+}-\mathrm{Ca}^{2+}-\mathrm{Mg}^{2+}-\mathrm{NH}_{4}^{+}-\mathrm{Na}^{+}-\mathrm{SO}_{4}^{2-}-\mathrm{NO}_{3}^{-}-\mathrm{Cl}^{-}-\mathrm{H}_{2} \mathrm{O}$ aerosol system to estimate the LWC. Therefore, the measured organic species such as diacids and related compounds are not included in ISORROPIA II. The model was run as a "reverse problem", in which temperature, relative humidity, and aerosol phase concentrations of water-soluble inorganic ions were used as input for the estimation of aerosol LWC.

\section{Results and discussion}

\subsection{Size-segregated aerosol chemical characteristics}

We use $2.1 \mu \mathrm{m}$ as a split diameter between the fine- and coarse-mode particles. Table 1 presents the concentrations of inorganic and carbonaceous species in the fine- and coarsemode aerosols. Abundances of organic matter $(\mathrm{OM})$ in the atmosphere are generally estimated by multiplying the measured OC mass concentrations with the conversion factor of 1.6 for urban aerosols and 2.1 for aged aerosols (Turpin and Lim, 2001). CHAAMS is located in the outflow region of East Asian aerosols and local anthropogenic activities are insignificant. Because the aerosols reaching Okinawa undergo the atmospheric oxidation during the long-range transport, the fraction of oxygenated organic species is often high (Takami et al., 2007; Irei et al., 2014; Kunwar and Kawamura, 2014). Therefore, we used the conversion factor of 2.1, instead of 1.6 for the calculation of OM.

$\mathrm{OM}$ was more enriched in fine-size fractions than in the coarse-size fractions (Table 1). The elevated level of OM in fine fractions on Okinawa suggests a substantial contribu- 
Table 1. Concentrations $\left(\mu \mathrm{g} \mathrm{m}^{-3}\right)$ of major inorganic ions and carbonaceous species in the fine- and coarse-mode aerosols on Okinawa Island in the western North Pacific.

\begin{tabular}{|c|c|c|c|c|c|c|c|c|}
\hline \multirow[t]{2}{*}{ Inorganic ions } & \multicolumn{4}{|c|}{ Fine mode ${ }^{\mathrm{a}}$} & \multicolumn{4}{|c|}{ Coarse mode ${ }^{b}$} \\
\hline & Mean & $\mathrm{SD}^{\mathrm{c}}$ & $\operatorname{Min}^{d}$ & Max..$^{\mathrm{e}}$ & Mean & SD & Min. & Max. \\
\hline & \multicolumn{8}{|c|}{ Water-soluble inorganic ions } \\
\hline & \multicolumn{8}{|c|}{ Cations } \\
\hline $\mathrm{Na}^{+}$ & 0.44 & 0.20 & 0.21 & 0.72 & 2.42 & 0.89 & 1.60 & 3.65 \\
\hline $\mathrm{NH}_{4}^{+}$ & 2.40 & 1.18 & 0.74 & 3.69 & 0.03 & 0.01 & 0.03 & 0.05 \\
\hline $\mathrm{K}^{+}$ & 0.14 & 0.06 & 0.04 & 0.21 & 0.09 & 0.02 & 0.07 & 0.12 \\
\hline $\mathrm{Mg}^{2+}$ & 0.07 & 0.02 & 0.04 & 0.10 & 0.34 & 0.11 & 0.24 & 0.49 \\
\hline $\mathrm{Ca}^{2+}$ & 0.06 & 0.02 & 0.04 & 0.09 & 0.41 & 0.19 & 0.15 & 0.60 \\
\hline \multirow[t]{2}{*}{ Total cations } & 3.12 & 1.22 & 1.28 & 4.37 & 3.29 & 1.02 & 2.55 & 4.82 \\
\hline & \multicolumn{8}{|c|}{ Anions } \\
\hline $\mathrm{MSA}^{-}$ & 0.04 & 0.01 & 0.03 & 0.06 & 0.01 & 0.00 & 0.00 & 0.01 \\
\hline $\mathrm{Cl}^{-}$ & 0.12 & 0.13 & 0.02 & 0.29 & 4.27 & 2.25 & 1.77 & 7.25 \\
\hline $\mathrm{NO}_{3}^{-}$ & 0.14 & 0.08 & 0.04 & 0.23 & 1.61 & 0.54 & 0.94 & 2.41 \\
\hline $\mathrm{SO}_{4}^{2-}$ & 10.1 & 4.85 & 2.88 & 14.9 & 1.46 & 0.44 & 0.69 & 1.81 \\
\hline \multirow[t]{2}{*}{ Total anions } & 10.4 & 4.73 & 3.33 & 15.1 & 7.35 & 2.20 & 5.69 & 10.6 \\
\hline & \multicolumn{8}{|c|}{ Total water-soluble ions } \\
\hline \multirow[t]{2}{*}{ Total water-soluble ions } & 13.5 & 5.95 & 4.61 & 19.5 & 10.6 & 3.22 & 8.33 & 15.4 \\
\hline & \multicolumn{8}{|c|}{ Carbonaceous components } \\
\hline WSOC & 1.12 & 0.49 & 0.31 & 1.61 & 0.33 & 0.13 & 0.15 & 0.52 \\
\hline $\mathrm{OC}$ & 1.62 & 0.59 & 0.62 & 2.12 & 0.60 & 0.17 & 0.36 & 0.82 \\
\hline $\mathrm{OM}$ & 3.43 & 1.31 & 1.30 & 4.87 & 1.25 & 0.36 & 0.75 & 1.73 \\
\hline $\mathrm{EC}$ & 0.05 & 0.03 & 0.00 & 0.09 & - & - & - & - \\
\hline $\mathrm{TC}$ & 1.67 & 0.65 & 0.62 & 2.41 & 0.60 & 0.17 & 0.36 & 0.82 \\
\hline
\end{tabular}

${ }^{\text {a }}$ Fine mode represents aerosol size of $D_{\mathrm{p}}<2.1 \mu \mathrm{m}$. ${ }^{\mathrm{b}}$ Coarse mode represents aerosol size of $D_{\mathrm{p}}>2.1 \mu \mathrm{m} .{ }^{\mathrm{c}}$ Standard deviation.

${ }^{\mathrm{d}}$ Minimum. ${ }^{\mathrm{e}}$ Maximum.

tion of organic aerosols primarily from combustion sources, and secondarily from photochemical processes during longrange atmospheric transport. The OM in fine-mode aerosol on Okinawa may consist of oxygenated organic compounds such as diacids, $\omega$-oxoacids, and $\alpha$-dicarbonyls. Okinawa was strongly affected by long-range transport of continental air masses from Siberia and Mongolia as well as North China and Korea (Fig. 2). It is difficult to specify the source regions of air masses for each sample set because the sampling duration was 3-5 days. Each sample contains mixed continental and oceanic air masses. Precipitation may have an insignificant effect on the transport of pollutants from the source region to Okinawa because air masses did not experience serious precipitation events during transport (Fig. S2a).

Sulfate is the most abundant anion in fine mode, whereas chloride is the dominant anion in coarse mode. The cation budget is largely controlled by ammonium in fine mode, whereas sodium is the most abundant cation in coarse mode. The high abundance of $\mathrm{SO}_{4}^{2-}$ in fine particles suggests a sig- nificant contribution of anthropogenic sources including industrial emissions in East Asia via long-range transport of aerosols over the western North Pacific Rim. $\mathrm{SO}_{4}^{2-}$ is an anthropogenic tracer of industrial activities whereas $\mathrm{NH}_{4}^{+}$is the secondary product of $\mathrm{NH}_{3}$ that is largely derived from the agricultural usage of nitrogen-based fertilizers (Pakkanen et al., 2001) and volatilization from soils and livestock waste in East Asia (Huang et al., 2006). The dominant presences of $\mathrm{Na}^{+}$and $\mathrm{Cl}^{-}$in coarse mode suggest a substantial contribution from sea salt. $\mathrm{Na}^{+}$and $\mathrm{Cl}^{-}$are emitted from the ocean surface as relatively larger particles. A substantial amount of $\mathrm{NO}_{3}^{-}$was detected in coarse mode, suggesting a formation of $\mathrm{Ca}\left(\mathrm{NO}_{3}\right)_{2}$ or $\mathrm{NaNO}_{3}$ in coarse fractions through the reactive adsorption of gaseous $\mathrm{HNO}_{3}$ onto preexisting alkaline particles.

The molecular distributions of detected diacids and related compounds in size-segregated aerosols are shown in Fig. 3. Table 2 presents the summarized concentrations of those compounds in fine and coarse modes. Oxalic acid $\left(\mathrm{C}_{2}\right)$ was 
Table 2. Summarized concentrations $\left(\mathrm{ng} \mathrm{m}^{-3}\right)$ of water-soluble dicarboxylic acids and related polar compounds in the fine- and coarse-mode aerosols from Okinawa Island in the western North Pacific Rim.

\begin{tabular}{|c|c|c|c|c|c|c|c|c|c|c|}
\hline \multirow[t]{2}{*}{ Compounds } & \multirow[t]{2}{*}{ Abbreviation } & \multirow[t]{2}{*}{ Chemical formula } & \multicolumn{4}{|c|}{ Fine mode ${ }^{\mathrm{a}}$} & \multicolumn{4}{|c|}{ Coarse mode ${ }^{b}$} \\
\hline & & & Mean & $\mathrm{SD}^{\mathrm{c}}$ & Min. $^{\mathrm{d}}$ & $\operatorname{Max}^{\mathrm{e}}$ & Mean & SD & Min. & Max. \\
\hline \multicolumn{11}{|c|}{ Dicarboxylic acids } \\
\hline \multicolumn{11}{|c|}{ Saturated normal-chain diacids } \\
\hline Oxalic & $\mathrm{C}_{2}$ & $\mathrm{HOOC}-\mathrm{COOH}$ & 135 & 37.4 & 76.0 & 176 & 40.2 & 14.7 & 22.1 & 60.0 \\
\hline Malonic & $\mathrm{C}_{3}$ & $\mathrm{HOOC}-\mathrm{CH}_{2}-\mathrm{COOH}$ & 19.5 & 6.84 & 7.56 & 23.6 & 12.4 & 3.52 & 6.87 & 15.5 \\
\hline Adipic & $\mathrm{C}_{6}$ & $\mathrm{HOOC}-\left(\mathrm{CH}_{2}\right)_{4}-\mathrm{COOH}$ & 3.49 & 1.09 & 2.47 & 4.98 & 2.50 & 1.24 & 1.45 & 4.23 \\
\hline Pimelic & $\mathrm{C}_{7}$ & $\mathrm{HOOC}-\left(\mathrm{CH}_{2}\right)_{5}-\mathrm{COOH}$ & 0.46 & 0.24 & 0.04 & 0.63 & 0.32 & 0.11 & 0.20 & 0.44 \\
\hline Suberic & $\mathrm{C}_{8}$ & $\mathrm{HOOC}-\left(\mathrm{CH}_{2}\right)_{6}-\mathrm{COOH}$ & 0.07 & 0.07 & 0.00 & 0.16 & 0.04 & 0.02 & 0.02 & 0.07 \\
\hline Azelaic & $\mathrm{C}_{9}$ & $\mathrm{HOOC}-\left(\mathrm{CH}_{2}\right)_{7}-\mathrm{COOH}$ & 1.20 & 0.72 & 0.51 & 2.41 & 1.15 & 0.60 & 0.49 & 2.10 \\
\hline Decanedioic & $\mathrm{C}_{10}$ & $\mathrm{HOOC}-\left(\mathrm{CH}_{2}\right)_{8}-\mathrm{COOH}$ & 0.17 & 0.11 & 0.01 & 0.30 & 0.08 & 0.07 & 0.03 & 0.19 \\
\hline Undecanedioic & $\mathrm{C}_{11}$ & $\mathrm{HOOC}-\left(\mathrm{CH}_{2}\right)_{9}-\mathrm{COOH}$ & 0.47 & 0.33 & 0.13 & 0.76 & 0.25 & 0.10 & 0.14 & 0.38 \\
\hline Methylsuccinic & $\mathrm{iC}_{5}$ & $\mathrm{HOOC}-\mathrm{CH}\left(\mathrm{CH}_{3}\right)-\mathrm{COOH}$ & 0.81 & 0.27 & 0.37 & 1.00 & 0.59 & 0.13 & 0.45 & 0.80 \\
\hline 2-Methylglutaric & $\mathrm{iC}_{6}$ & $\mathrm{HOOC}-\mathrm{CH}\left(\mathrm{CH}_{3}\right)-\left(\mathrm{CH}_{2}\right)_{2}-\mathrm{COOH}$ & 0.35 & 0.24 & 0.05 & 0.70 & 0.19 & 0.20 & 0.04 & 0.53 \\
\hline \multicolumn{11}{|c|}{ Unsaturated aliphatic diacids } \\
\hline Maleic & M & $\mathrm{HOOC}-\mathrm{CH}=\mathrm{CH}-\mathrm{COOH}-$ cis & 0.81 & 0.25 & 0.41 & 1.05 & 0.73 & 0.23 & 0.37 & 0.95 \\
\hline Fumaric & $\mathrm{F}$ & $\mathrm{HOOC}-\mathrm{CH}=\mathrm{CH}-\mathrm{COOH}-$ trans & 0.31 & 0.09 & 0.20 & 0.42 & 0.21 & 0.08 & 0.12 & 0.30 \\
\hline Methylmaleic & $\mathrm{mM}$ & $\mathrm{HOOC}-\mathrm{C}\left(\mathrm{CH}_{3}\right)=\mathrm{CH}-\mathrm{COOH}-\mathrm{cis}$ & 0.34 & 0.27 & 0.11 & 0.76 & 0.57 & 0.48 & 0.11 & 1.37 \\
\hline \multicolumn{11}{|c|}{ Unsaturated aromatic diacids } \\
\hline Phthalic & $\mathrm{Ph}$ & HOOC- $\left(\mathrm{C}_{6} \mathrm{H}_{4}\right)-\mathrm{COOH}$ - o-isomer & 6.29 & 2.85 & 1.99 & 9.3 & 2.79 & 0.81 & 1.85 & 3.9 \\
\hline Isophthalic & $\mathrm{iPh}$ & HOOC- $\left(\mathrm{C}_{6} \mathrm{H}_{4}\right)-\mathrm{COOH}$ - m-isomer & 0.46 & 0.07 & 0.35 & 0.55 & 0.17 & 0.06 & 0.09 & 0.22 \\
\hline Terephthalic & $\mathrm{tPh}$ & HOOC- $\left(\mathrm{C}_{6} \mathrm{H}_{4}\right)-\mathrm{COOH}$ - p-isomer & 2.21 & 1.15 & 0.32 & 3.30 & 0.64 & 0.38 & 0.09 & 1.17 \\
\hline Glyoxylic & $\omega \mathrm{C}_{2}$ & $\mathrm{OHC}-\mathrm{COOH}$ & 14.1 & 5.92 & 4.77 & 20.2 & 4.81 & 2.00 & 2.23 & 7.20 \\
\hline 3-Oxopropanoic & $\omega \mathrm{C}_{3}$ & $\mathrm{OHC}-\mathrm{CH}_{2}-\mathrm{COOH}$ & 0.08 & 0.05 & 0.00 & 0.12 & 0.05 & 0.04 & 0.02 & 0.12 \\
\hline 4-Oxobutanoic & $\omega \mathrm{C}_{4}$ & $\mathrm{OHC}-\left(\mathrm{CH}_{2}\right)_{2}-\mathrm{COOH}$ & 2.23 & 1.12 & 0.86 & 3.56 & 0.68 & 0.35 & 0.41 & 1.22 \\
\hline 9-Oxononanoic & $\omega \mathrm{C}_{9}$ & $\mathrm{OHC}-\left(\mathrm{CH}_{2}\right)_{7}-\mathrm{COOH}$ & 0.74 & 0.20 & 0.54 & 1.07 & 1.06 & 0.34 & 0.57 & 1.41 \\
\hline Total oxoacids & & & 17.1 & 7.04 & 6.27 & 25.0 & 6.60 & 2.33 & 3.26 & 9.52 \\
\hline \multicolumn{11}{|c|}{ Ketoacid } \\
\hline Pyruvic & Pyr & $\mathrm{CH}_{3}-\mathrm{C}(\mathrm{O})-\mathrm{COOH}$ & 2.61 & 0.76 & 1.67 & 3.48 & 2.32 & 1.20 & 0.76 & 4.09 \\
\hline \multicolumn{11}{|c|}{$\alpha$-Dicarbonyls } \\
\hline Glyoxal & Gly & $\mathrm{OHC}-\mathrm{CHO}$ & 2.74 & 1.12 & 1.45 & 4.40 & 0.84 & 0.26 & 0.50 & 1.17 \\
\hline Methylglyoxal & MeGly & $\mathrm{CH}_{3}-\mathrm{C}(\mathrm{O})-\mathrm{CHO}$ & 1.09 & 0.98 & 0.25 & 2.53 & 0.65 & 0.16 & 0.45 & 0.87 \\
\hline \multicolumn{2}{|c|}{ Total $\alpha$-dicarbonyls } & & 2.83 & 1.59 & 1.03 & 4.68 & 1.49 & 0.37 & 0.96 & 1.86 \\
\hline \multicolumn{11}{|c|}{ Aromatic monoacid } \\
\hline Benzoic acid & & $\mathrm{C}_{6} \mathrm{H}_{5}-\mathrm{COOH}$ & 16.5 & 11.0 & 4.57 & 28.3 & 1.98 & 1.01 & 0.70 & 3.38 \\
\hline
\end{tabular}

${ }^{\mathrm{a}}$ Fine mode represents aerosol size of $D_{\mathrm{p}}<2.1 \mu \mathrm{m} .{ }^{\mathrm{b}}$ Coarse mode represents aerosol size of $D_{\mathrm{p}}>2.1 \mu \mathrm{m} .{ }^{\mathrm{c}}$ Standard deviation. ${ }^{\mathrm{d}}$ Minimum. ${ }^{\mathrm{e}}$ Maximum. 

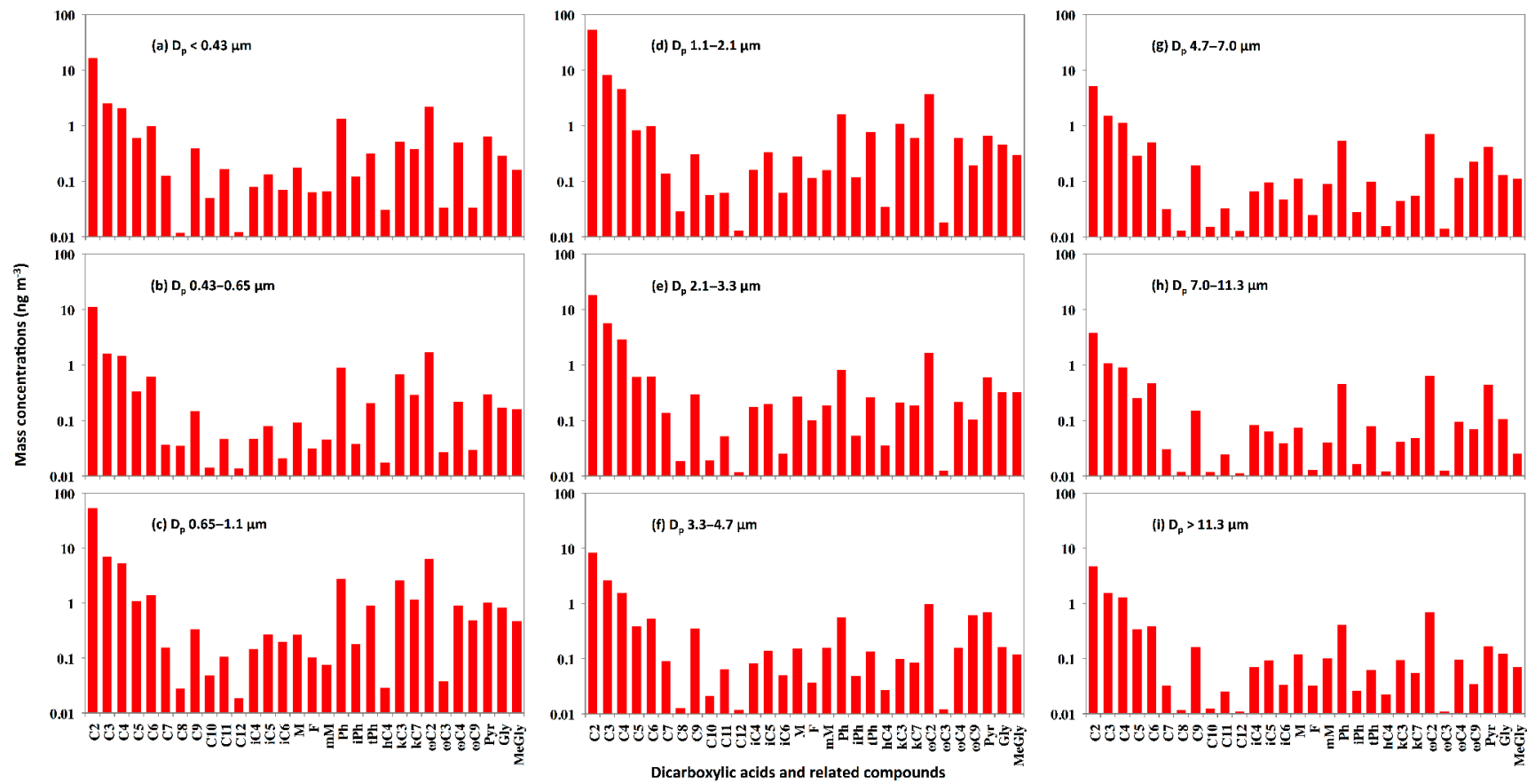

Figure 3. Average molecular distributions of water-soluble dicarboxylic acids and related compounds in size-segregated aerosols collected on Okinawa Island.

found to be the most abundant diacid followed by malonic $\left(\mathrm{C}_{3}\right)$ and succinic $\left(\mathrm{C}_{4}\right)$ acids in all size-segregated aerosols. The predominance of $\mathrm{C}_{2}$ in size-segregated aerosols is due to the fact that it can be secondarily produced by the photooxidation of anthropogenic and biogenic organic precursors in gas and aqueous phase (Kawamura and Sakaguchi, 1999; Warneck, 2003; Carlton et al., 2006). $\mathrm{C}_{2}$ can also be produced primarily from fossil fuel combustion (Kawamura and Kaplan, 1987) and biomass burning (Kundu et al., 2010) in East Asia and is long-range-transported to Okinawa.

Phthalic $(\mathrm{Ph})$ and adipic $\left(\mathrm{C}_{6}\right)$ acids are the next abundant diacids, whereas ketomalonic acid $\left(\mathrm{kC}_{3}\right)$ is more abundant than $\mathrm{C}_{6}$ diacid in the size ranges of $0.43-0.65$ to $0.65-1.1 \mu \mathrm{m}$ (Fig. 3). $\mathrm{Ph}$ and $\mathrm{C}_{6}$ diacids originate from various anthropogenic sources and thus they can be used as anthropogenic tracers. Ph primarily originates from coal burning and vehicular emissions, whereas photooxidation of aromatic hydrocarbons such as naphthalene and o-xylene derived from incomplete combustion of fossil fuel form $\mathrm{Ph}$ via secondary processes (Kawamura and Kaplan, 1987). Moreover, abundant presence of $\mathrm{Ph}$ may also be caused by enhanced emission of phthalates from plastics used in heavily populated and industrialized regions in China and the subsequent longrange atmospheric transport to Okinawa. Phthalic acid esters are used as plasticizers in resins and polymers (Simoneit et al., 2005). They can be released into the air by evaporation because they are not chemically bonded to the polymer. Kawamura and Usukura (1993) reported that $C_{6}$ diacid is an oxidation product through the reaction of cyclohexene with ozone $\left(\mathrm{O}_{3}\right)$. The high abundances of $\mathrm{Ph}$ and $\mathrm{C}_{6}$ diacids on Okinawa suggest a significant influence of anthropogenic sources in East Asia via long-range transport of aerosols over the western North Pacific Rim.

Azelaic acid $\left(\mathrm{C}_{9}\right)$ is more abundant than adjacent suberic $\left(\mathrm{C}_{8}\right)$ and decanedioic $\left(\mathrm{C}_{10}\right)$ acids in all the sizesegregated aerosols (Fig. 3 and Table 2). Kawamura and Gagosian (1987) proposed that $\mathrm{C}_{9}$ is a photooxidation product of biogenic unsaturated fatty acids such as oleic acid $\left(\mathrm{C}_{18: 1}\right)$ containing a double bond at $\mathrm{C}-9$ position. Unsaturated fatty acids can be emitted from sea surface microlayers and from local vegetation on Okinawa (Kunwar and Kawamura, 2014). Moreover, Okinawa was affected by long-range transport of air masses from Siberia and Mongolia as well as North China and Korea (Fig. 2). Such continental air masses can also deliver $\mathrm{C}_{9}$ via atmospheric processing of unsaturated fatty acids during long-range transport. The abundant presence of $\mathrm{C}_{9}$ indicates that atmospheric oxidation of unsaturated fatty acids also occurs in Okinawa aerosols during longrange transport. $\omega$-Oxocarboxylic acids and $\alpha$-dicarbonyls were detected in the Okinawa aerosols. Glyoxylic acid $\left(\omega \mathrm{C}_{2}\right)$ was identified as the most abundant $\omega$-oxoacid, whereas glyoxal (Gly) was more abundant than methylglyoxal (MeGly) in all the sizes. $\omega \mathrm{C}_{2}$ and Gly are the oxidation products of several anthropogenic and biogenic VOCs and are primarily generated by fossil fuel combustion and biomass burning (Zimmermann and Poppe, 1996; Volkamer et al., 2001), and are further oxidized to $\mathrm{C}_{2}$ diacid (Myriokefalitakis et al., 
Table 3. Pearson correlation coefficients ${ }^{\mathrm{a}}(r)$ matrix among the selected chemical species/components measured in the fine- and coarse-mode aerosols from Okinawa Island in the western North Pacific Rim.

\begin{tabular}{|c|c|c|c|c|c|c|c|c|c|c|c|c|c|c|c|c|c|c|c|c|c|c|}
\hline & \multicolumn{22}{|c|}{ Fine mode ${ }^{b}$} \\
\hline & $\mathrm{Na}^{+}$ & $\mathrm{NH}_{4}^{+}$ & $\mathrm{K}^{+}$ & $\mathrm{Mg}^{2+}$ & $\mathrm{Ca}^{2+}$ & $\mathrm{MSA}^{-}$ & $\mathrm{Cl}^{-}$ & $\mathrm{NO}_{3}^{-}$ & $\mathrm{SO}_{4}^{2-}$ & WSOC & $\mathrm{OC}$ & $\mathrm{C}_{2}$ & $\mathrm{C}_{3}$ & $\mathrm{C}_{4}$ & $\mathrm{C}_{5}$ & $\mathrm{C}_{9}$ & $\mathrm{Ph}$ & $\omega \mathrm{C}_{2}$ & $\omega \mathrm{C}_{9}$ & Gly & Benzoic & LWC \\
\hline $\mathrm{Na}^{+}$ & 1.00 & & & & & & & & & & & & & & & & & & & & & \\
\hline $\mathrm{NH}_{4}^{+}$ & -0.25 & 1.00 & & & & & & & & & & & & & & & & & & & & \\
\hline $\mathrm{K}^{+4}$ & -0.32 & 0.99 & 1.00 & & & & & & & & & & & & & & & & & & & \\
\hline $\mathrm{Mg}^{2+}$ & 0.98 & -0.16 & -0.23 & 1.00 & & & & & & & & & & & & & & & & & & \\
\hline $\mathrm{Ca}^{2+}$ & -0.21 & 0.62 & 0.33 & -0.15 & 1.00 & & & & & & & & & & & & & & & & & \\
\hline MSA $^{-}$ & -0.32 & 0.92 & 0.92 & -0.17 & 0.53 & 1.00 & & & & & & & & & & & & & & & & \\
\hline $\mathrm{Cl}^{-}$ & 0.65 & -0.85 & -0.85 & 0.58 & -0.33 & -0.78 & 1.00 & & & & & & & & & & & & & & & \\
\hline $\mathrm{NO}_{3}^{-}$ & 0.65 & -0.56 & -0.55 & 0.68 & 0.22 & -0.36 & 0.76 & 1.00 & & & & & & & & & & & & & & \\
\hline $\mathrm{SO}_{4}^{2-}$ & -0.10 & 0.99 & 0.98 & -0.02 & 0.59 & 0.89 & -0.78 & -0.49 & 1.00 & & & & & & & & & & & & & \\
\hline WSOC & 0.10 & 0.91 & 0.93 & 0.16 & 0.30 & 0.79 & -0.57 & -0.27 & 0.96 & 1.00 & & & & & & & & & & & & \\
\hline $\mathrm{OC}$ & 0.12 & 0.91 & 0.95 & 0.16 & 0.25 & 0.80 & -0.57 & -0.32 & 0.93 & 0.99 & 1.00 & & & & & & & & & & & \\
\hline $\mathrm{C}_{2}$ & 0.12 & 0.89 & 0.85 & -0.13 & 0.22 & 0.80 & -0.53 & -0.30 & 0.92 & 0.99 & 0.98 & 1.00 & & & & & & & & & & \\
\hline $\mathrm{C}_{3}$ & -0.05 & 0.90 & 0.89 & -0.05 & 0.20 & 0.66 & -0.68 & -0.53 & 0.90 & 0.93 & 0.96 & 0.89 & 1.00 & & & & & & & & & \\
\hline $\mathrm{C}_{4}$ & -0.12 & 0.96 & 0.95 & -0.09 & 0.15 & 0.76 & -0.75 & -0.55 & 0.96 & 0.95 & 0.96 & 0.92 & 0.99 & 1.00 & & & & & & & & \\
\hline $\mathrm{C}_{5}$ & -0.12 & 0.99 & 0.96 & -0.05 & 0.33 & 0.87 & -0.80 & -0.53 & 0.99 & 0.93 & 0.93 & 0.91 & 0.95 & 0.97 & 1.00 & & & & & & & \\
\hline $\mathrm{C}_{9}$ & 0.64 & 0.01 & 0.02 & 0.61 & 0.42 & -0.16 & 0.46 & 0.47 & 0.10 & 0.20 & 0.39 & 0.38 & 0.33 & 0.23 & 0.09 & 1.00 & & & & & & \\
\hline $\mathrm{Ph}$ & 0.41 & 0.78 & 0.73 & 0.46 & 0.42 & 0.63 & -0.40 & -0.16 & 0.87 & 0.92 & 0.93 & 0.90 & 0.83 & 0.83 & 0.86 & 0.23 & 1.00 & & & & & \\
\hline$\omega \mathrm{C}_{2}$ & 0.11 & 0.92 & 0.90 & 0.19 & 0.19 & 0.82 & -0.57 & -0.25 & 0.96 & 0.99 & 0.99 & 0.99 & 0.90 & 0.93 & 0.95 & 0.36 & 0.93 & 1.00 & & & & \\
\hline$\omega \mathrm{C}_{9}$ & 0.23 & 0.22 & 0.12 & 0.18 & -0.56 & -0.01 & -0.32 & -0.53 & 0.29 & 0.13 & 0.22 & 0.05 & 0.31 & 0.26 & 0.32 & 0.80 & 0.02 & 0.16 & 1.00 & & & \\
\hline Gly & 0.01 & 0.86 & 0.86 & 0.15 & 0.09 & 0.92 & -0.52 & -0.07 & 0.86 & 0.89 & 0.82 & 0.93 & 0.70 & 0.78 & 0.85 & 0.21 & 0.85 & 0.92 & -0.11 & 1.00 & & \\
\hline Benzoic & -0.13 & 0.99 & 0.99 & -0.05 & -0.23 & 0.90 & -0.27 & 0.46 & 0.99 & 0.96 & 0.99 & 0.93 & 0.91 & 0.96 & 0.99 & 0.12 & 0.85 & 0.96 & 0.21 & 0.90 & 1.00 & \\
\hline LWC & 0.16 & 0.87 & 0.83 & 0.30 & 0.53 & 0.88 & -0.53 & -0.13 & 0.92 & 0.90 & 0.87 & 0.92 & 0.82 & 0.83 & 0.89 & 0.18 & 0.90 & 0.95 & 0.19 & 0.95 & 0.91 & 1.00 \\
\hline \multicolumn{23}{|c|}{ Coarse mode ${ }^{\mathrm{c}}$} \\
\hline & $\mathrm{Na}^{+}$ & $\mathrm{NH}_{4}^{+}$ & $\mathrm{K}^{+}$ & $\mathrm{Mg}^{2+}$ & $\mathrm{Ca}^{2+}$ & $\mathrm{MSA}^{-}$ & $\mathrm{Cl}^{-}$ & $\mathrm{NO}_{3}^{-}$ & $\mathrm{SO}_{4}^{2-}$ & WSOC & $\mathrm{OC}$ & $\mathrm{C}_{2}$ & $\mathrm{C}_{3}$ & $\mathrm{C}_{4}$ & $\mathrm{C}_{5}$ & $\mathrm{C}_{9}$ & $\mathrm{Ph}$ & $\omega \mathrm{C}_{2}$ & $\omega \mathrm{C}_{9}$ & Gly & Benzoic & LWC \\
\hline $\mathrm{Na}^{+}$ & 1.00 & & & & & & & & & & & & & & & & & & & & & \\
\hline $\mathrm{NH}_{4}^{+}$ & 0.60 & 1.00 & & & & & & & & & & & & & & & & & & & & \\
\hline $\mathrm{K}^{+4}$ & 0.96 & 0.77 & 1.00 & & & & & & & & & & & & & & & & & & & \\
\hline $\mathrm{Mg}^{2+}$ & 0.98 & 0.63 & 0.33 & 1.00 & & & & & & & & & & & & & & & & & & \\
\hline $\mathrm{Ca}^{2+}$ & -0.12 & 0.03 & -0.06 & -0.29 & 1.00 & & & & & & & & & & & & & & & & & \\
\hline MSA $^{-}$ & -0.15 & -0.66 & -0.03 & -0.25 & -0.02 & 1.00 & & & & & & & & & & & & & & & & \\
\hline $\mathrm{Cl}^{-}$ & 0.98 & 0.59 & 0.90 & 0.98 & -0.27 & -0.22 & 1.00 & & & & & & & & & & & & & & & \\
\hline $\mathrm{NO}_{3}^{-}$ & -0.30 & -0.23 & -0.15 & -0.39 & 0.98 & 0.28 & -0.55 & 1.00 & & & & & & & & & & & & & & \\
\hline $\mathrm{SO}_{4}^{2-}$ & 0.33 & 0.32 & 0.56 & 0.28 & 0.63 & 0.25 & 0.16 & 0.67 & 1.00 & & & & & & & & & & & & & \\
\hline WSOC & -0.18 & -0.26 & 0.06 & -0.20 & 0.23 & 0.55 & -0.36 & 0.92 & 0.72 & 1.00 & & & & & & & & & & & & \\
\hline $\mathrm{OC}$ & -0.11 & -0.10 & 0.13 & -0.10 & 0.21 & 0.36 & -0.28 & 0.92 & 0.72 & 0.97 & 1.00 & & & & & & & & & & & \\
\hline $\mathrm{C}_{2}$ & -0.05 & 0.26 & 0.30 & 0.15 & 0.63 & 0.09 & -0.08 & 0.88 & 0.76 & 0.93 & 0.82 & 1.00 & & & & & & & & & & \\
\hline $\mathrm{C}_{3}$ & 0.32 & 0.33 & 0.53 & 0.31 & 0.68 & 0.18 & 0.15 & 0.75 & 0.92 & 0.88 & 0.82 & 0.93 & 1.00 & & & & & & & & & \\
\hline $\mathrm{C}_{4}$ & 0.33 & 0.39 & 0.60 & 0.35 & 0.53 & 0.16 & 0.33 & 0.32 & 0.88 & 0.31 & 0.55 & 0.36 & 0.63 & 1.00 & & & & & & & & \\
\hline $\mathrm{C}_{5}$ & 0.05 & 0.05 & 0.22 & -0.06 & 0.62 & 0.32 & -0.05 & 0.43 & 0.75 & 0.28 & 0.38 & 0.22 & 0.45 & 0.91 & 1.00 & & & & & & & \\
\hline $\mathrm{C}_{9}$ & 0.85 & 0.20 & 0.25 & 0.91 & -0.16 & -0.59 & 0.85 & -0.31 & 0.18 & -0.08 & -0.25 & 0.25 & 0.30 & 0.19 & -0.23 & 1.00 & & & & & & \\
\hline $\mathrm{Ph}$ & -0.52 & -0.54 & -0.29 & -0.54 & 0.73 & 0.59 & -0.66 & 0.93 & 0.54 & 0.56 & 0.33 & 0.63 & 0.58 & 0.21 & 0.40 & -0.58 & 1.00 & & & & & \\
\hline$\omega \mathrm{C}_{2}$ & 0.23 & 0.37 & 0.85 & 0.68 & 0.12 & 0.42 & 0.59 & 0.23 & 0.73 & 0.53 & 0.52 & 0.53 & 0.76 & 0.60 & 0.32 & 0.23 & 0.21 & 1.00 & & & & \\
\hline$\omega \mathrm{C}_{9}$ & 0.83 & 0.53 & 0.82 & 0.87 & -0.33 & 0.03 & 0.80 & -0.22 & 0.21 & 0.07 & 0.16 & 0.28 & 0.38 & 0.08 & -0.31 & 0.93 & -0.28 & 0.33 & 1.00 & & & \\
\hline Gly & 0.26 & 0.26 & 0.78 & 0.57 & 0.05 & 0.52 & 0.58 & 0.06 & 0.69 & 0.28 & 0.33 & 0.22 & 0.55 & 0.76 & 0.57 & 0.24 & 0.12 & 0.89 & 0.13 & 1.00 & & \\
\hline Benzoic & -0.40 & -0.60 & -0.57 & -0.36 & -0.70 & 0.17 & -0.29 & -0.43 & -0.88 & -0.40 & -0.35 & -0.57 & -0.73 & -0.91 & -0.77 & -0.37 & 0.19 & -0.48 & -0.07 & -0.51 & 1.00 & \\
\hline LWC & 0.61 & 0.03 & 0.53 & 0.56 & -0.70 & 0.48 & 0.63 & -0.51 & -0.10 & -0.19 & -0.13 & -0.29 & -0.08 & -0.03 & -0.22 & 0.23 & -0.31 & 0.57 & 0.25 & 0.63 & 0.31 & 1.00 \\
\hline
\end{tabular}

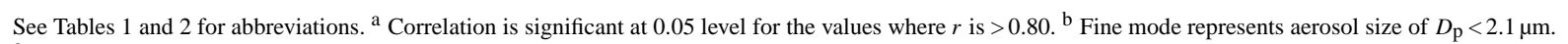

${ }^{\mathrm{c}}$ Coarse mode represents aerosol size of $D_{\mathrm{p}}>2.1 \mu \mathrm{m}$.

2011). The predominance of $\omega \mathrm{C}_{2}$ and Gly indicates their importance as key precursors of $\mathrm{C}_{2}$ in Okinawa aerosols.

\subsection{Inorganic species}

The particle size distributions of major ions are shown in Fig. 4. Pearson correlation coefficients $(r)$ among the measured ions in different size modes are given in Table $3 . \mathrm{Na}^{+}$ and $\mathrm{Cl}^{-}$are mainly derived from the ocean surface as sea salt particles in the marine atmosphere (Kumar et al., 2008; Geng et al., 2009). The size distributions of $\mathrm{Na}^{+}$and $\mathrm{Cl}^{-}$ were found to be bimodal with two peaks in coarse mode (Fig. $4 \mathrm{a}$ and b). Their peaks at $2.1-3.3$ or $3.3-4.7 \mu \mathrm{m}$ and at $>11.3 \mu \mathrm{m}$ suggest that they are of marine origin due to bubble bursting of surface seawater. Andreas (1998) suggested that the sea spray falls into two types that are defined as film and jet bubbles; film bubbles correspond to the size of $0.5-5 \mu \mathrm{m}$, whereas jet bubbles are produced the size of 5-20 $\mu \mathrm{m}$. Their coarse-mode peaks at $2.1-3.3 \mu \mathrm{m}$ or $3.3-4.7$ and $>11.3 \mu \mathrm{m}$ in
Okinawa aerosols were associated with film and jet bubbles. We found that size distribution of $\mathrm{Mg}^{2+}$ is similar to those of $\mathrm{Na}^{+}$and $\mathrm{Cl}^{-}$with a significant positive correlation to coarsemode $\mathrm{Na}^{+}$and $\mathrm{Cl}^{-}(r=0.98)$, suggesting their similar origin and sources.

A high concentration of $\mathrm{Ca}^{2+}$ in coarse-mode particles demonstrates its contribution from soil dust (Kerminen et al., 1997a; Tsai and Chen, 2006). A lifting of soil dust in continental sites followed by subsequent long-range atmospheric transport to a remote marine site is also proposed as an important source of $\mathrm{Ca}^{2+}$ (Y. Wang et al., 2005). $\mathrm{Ca}^{2+}$ showed unimodal distribution with a peak at either $2.1-3.3$ or 3.3$4.7 \mu \mathrm{m}$ (Fig. 4c). The coarse-mode $\mathrm{Ca}^{2+}$ is mostly derived from crustal $\mathrm{CaCO}_{3}$, which heterogeneously reacts with acidic gases $\left(\mathrm{HNO}_{3}\right.$ and $\left.\mathrm{SO}_{2}\right)$ (Kerminen et al., 1997a). This formation mechanism is further supported by a strong correlation of coarse-mode $\mathrm{Ca}^{2+}$ with $\mathrm{NO}_{3}^{-}(r=0.98)$. There is no correlation between $\mathrm{Ca}^{2+}$ and $\mathrm{Na}^{+}$or $\mathrm{Cl}^{-}(r=-0.12$ or $-0.27)$, revealing that sea salt contribution of $\mathrm{Ca}^{2+}$ is neg- 

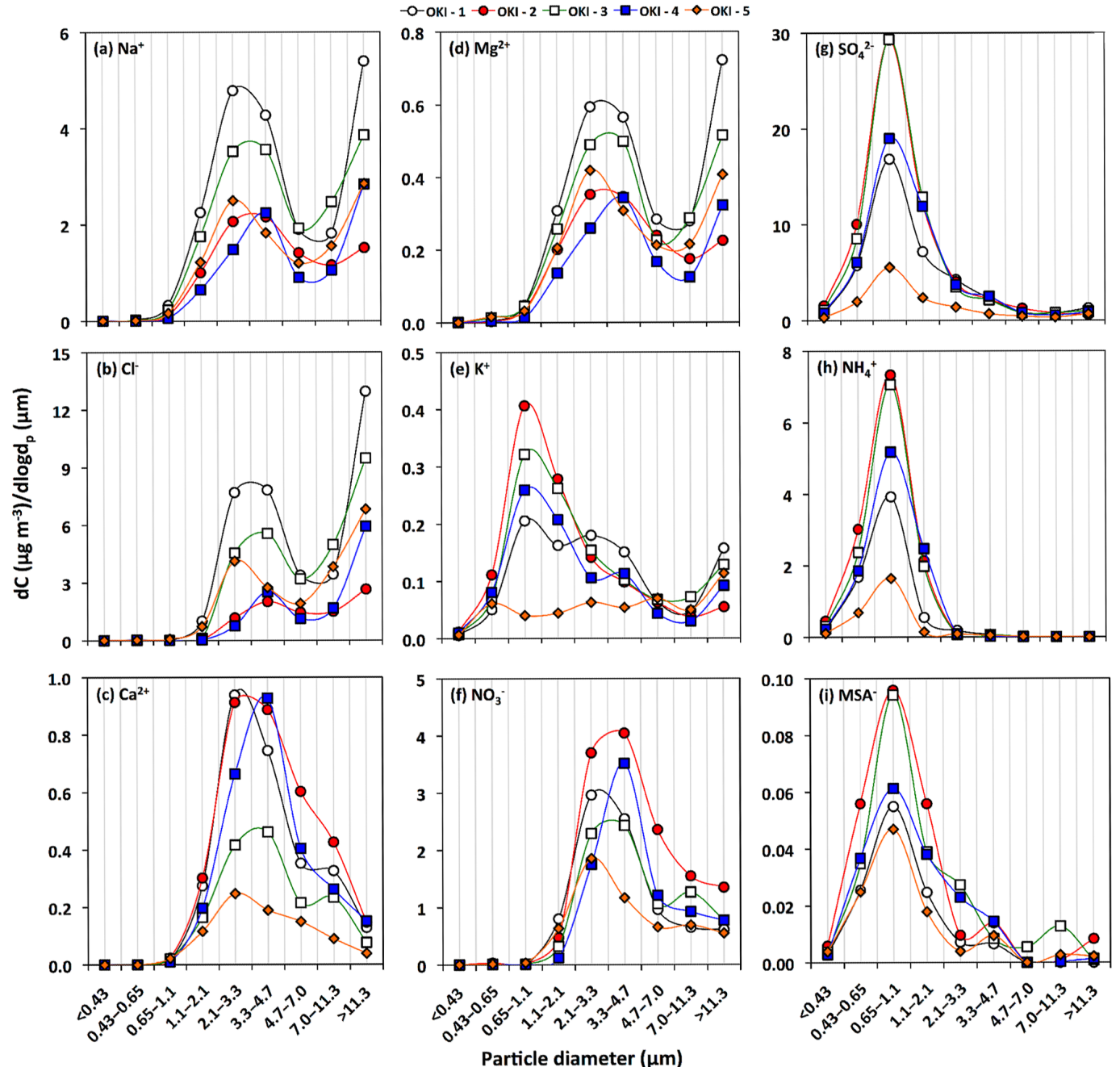

Figure 4. Size distributions of water-soluble inorganic ions in the aerosol samples collected on Okinawa Island.

ligible in Okinawa aerosols. This result suggests that longrange transport of soil dust is an important contributor of $\mathrm{Ca}^{2+}$ in the marine aerosols from the western North Pacific Rim.

There are natural limestone caves formed by elevated coral reefs on Okinawa Island. Although local limestone dust may also be resuspended in the atmosphere by wind (Shimada et al., 2015), the local dust contribution to the ambient level of $\mathrm{Ca}^{2+}$ on Okinawa may be small. This interpretation can be supported by the fact that $\mathrm{Ca}^{2+}$ peaked in lower coarse size range of $2.1-3.3$ or $3.3-4.7 \mu \mathrm{m}$. It has been suggested that $\mathrm{Ca}^{2+}$ is likely associated with upper coarse size range when the contribution of locally produced soil particles is significant (Bian et al., 2014). Smaller coarse-mode $\mathrm{Ca}^{2+}$ is likely associated with long-range-transported Asian dust to Okinawa. Moreover, concentrations of $\mathrm{Ca}^{2+}$ in coarse mode were found to be much higher in OKI-1 $\left(0.51 \mu \mathrm{g} \mathrm{m}^{-3}\right)$ and OKI-2 $\left(0.60 \mu \mathrm{g} \mathrm{m}^{-3}\right)$ than that in the OKI-5 sample $\left(0.15 \mu \mathrm{g} \mathrm{m}^{-3}\right)$. Backward trajectories also indicated that the air masses which originated from Mongolia and Siberia were transported to Okinawa during the collection of OKI-1 and OKI-2 samples, whereas the OKI-5 sample has an influence of marine air masses. Such air mass origin again indicates the long-range transport of Asian dust from East Asia to the western North Pacific.

Potassium is enriched in biomass burning aerosols and therefore its abundances in fine particles can serve as a diagnostic tracer of biomass burning (Yamasoe et al., 2000). Moreover, contributions of $\mathrm{K}^{+}$from sea salt and dust sources are highly variable in regional case studies, with its dominance in coarse-mode particles. Fresh biomass burning particles mostly reside in the condensation mode at $0.1-0.5 \mu \mathrm{m}$ in diameter (Kaufman and Fraser, 1997; Kleeman and Cass, 1999). A unimodal size distribution of $\mathrm{K}^{+}$was observed in most sample sets (OKI- 1 to OKI-4), with a peak at 0.65 $1.1 \mu \mathrm{m}$ in diameter (Fig. 4e). The peak of $\mathrm{K}^{+}$at $0.65-1.1 \mu \mathrm{m}$ suggests that biomass burning particles emitted in East Asia might have undergone growth to a relatively large size by 
absorbing water vapor from the atmosphere during longrange transport to Okinawa. This interpretation is supported by the fact that $\mathrm{K}^{+}$showed a positive correlation with LWC $(r=0.83)$ in fine mode. The fine-mode nss- $\mathrm{K}^{+}$accounted for $95 \%$ of total $\mathrm{K}^{+}$in the OKI-2 sample set and $88 \%$ of that in the OKI-3 sample set when air masses come from Siberia and Mongolia as well as North China. The abundant presence of fine-mode nss- $\mathrm{K}^{+}$in the OKI-2 and OKI-3 samples further indicates a long-range atmospheric transport of biomass burning aerosols from the Asian continent to the western North Pacific Rim.

$\mathrm{NO}_{x}$ is a precursor of $\mathrm{NO}_{3}^{-}$, which can be converted to $\mathrm{HNO}_{3}$ and then react with $\mathrm{NH}_{3}$ to form $\mathrm{NH}_{4} \mathrm{NO}_{3}$. A unimodal size distribution of $\mathrm{NO}_{3}^{-}$was observed with a peak at $2.1-3.3$ or $3.3-4.7 \mu \mathrm{m}$ in diameter (Fig. 4f). It should also be noted that the $\mathrm{NO}_{3}^{-}$concentration in coarse mode is much higher than that in fine mode (Table 1). This result suggests that either dust or sea salt particles are the source of coarse-mode $\mathrm{NO}_{3}^{-}$on Okinawa. Coarse-mode $\mathrm{NO}_{3}^{-}$is produced by heterogeneous reaction of gaseous $\mathrm{NO}_{2}$ or $\mathrm{HNO}_{3}$ with alkaline metals such as $\mathrm{Na}^{+}$and $\mathrm{Ca}^{2+}$ as shown in Reactions (R1) and (R2) (Kouyoumdjian and Saliba, 2006; Seinfeld and Pandis, 2006).

$$
\begin{aligned}
& \mathrm{HNO}_{3(\mathrm{~g})}+\mathrm{NaCl}_{(\mathrm{aq} \text { and } \mathrm{s})} \rightarrow \mathrm{NaNO}_{3(\text { aq and } \mathrm{s}}+\mathrm{HCl}_{(\mathrm{g})} \\
& 2 \mathrm{HNO}_{3(\mathrm{~g})}+\mathrm{CaCO}_{3(\mathrm{~s})} \rightarrow \mathrm{Ca}\left(\mathrm{NO}_{3}\right)_{2(\mathrm{~s})}+\mathrm{H}_{2} \mathrm{O}+\mathrm{CO}_{2(\mathrm{~g})}
\end{aligned}
$$

As discussed earlier, the air masses which originated from Siberia are transported over Mongolia and North China. Asian dust can be transported from the Asian continent to Okinawa. Therefore, it is possible that the gaseous $\mathrm{HNO}_{3}$ might already have reacted with $\mathrm{CaCO}_{3}$ (mineral dust particle) to form $\mathrm{NO}_{3}^{-}$before arriving to Okinawa through R-2. We found that coarse-mode $\mathrm{Na}^{+}$, which is derived from sea salts, is negatively correlated $(r=-0.30)$ with coarse-mode $\mathrm{NO}_{3}^{-}$. Although this correlation is not significant $(p=0.51)$, the negative correlation may indicate some reactive loss of $\mathrm{NO}_{3}^{-}$from sea salt particles in coarse mode on Okinawa. $\mathrm{NO}_{3}^{-}$peaked at the same particle size of $\mathrm{Ca}^{2+}$. Therefore, $\mathrm{NO}_{3}^{-}$in Okinawa coarse-mode aerosols probably resulted from the uptake of $\mathrm{HNO}_{3}$ gas by soil dust particles enriched with $\mathrm{Ca}^{2+}$ via heterogeneous reactions near the source regions. This process is further supported by a good correlation between $\mathrm{NO}_{3}^{-}$and $\mathrm{Ca}^{2+}(r=0.98)$ in coarse mode.

The particle size distributions of $\mathrm{SO}_{4}^{2-}$, which is a major source of acid deposition (Pakkanen et al., 2001), have been the subject of numerous studies in the past few decades (Huang et al., 2006; Kouyoumdjian and Saliba, 2006). Condensation-mode $\mathrm{SO}_{4}^{2-}$ arises from gas-phase oxidation of $\mathrm{SO}_{2}$ followed by gas-to-particle conversion, whereas finemode $\mathrm{SO}_{4}^{2-}$ is formed through aqueous-phase oxidation of $\mathrm{SO}_{2}$ in aerosols and cloud droplets (Seinfeld and Pandis, 1998). $\mathrm{SO}_{4}^{2-}$ on coarse mode can be attributed to a combination of sulfate and heterogeneous reactions of $\mathrm{SO}_{2}$ on soil dust or sea salt particles (Seinfeld and Pandis, 1998;
Pakkanen et al., 2001). A unimodal size distribution of $\mathrm{SO}_{4}^{2-}$ was observed with a peak at $0.65-1.1 \mu \mathrm{m}$ (Fig. $4 \mathrm{~g}$ ). Gao et al. (2012) suggested that an in-cloud process produces $\mathrm{SO}_{4}^{2-}$ as larger particles by aqueous-phase oxidation of $\mathrm{SO}_{2}$ in cloud droplets. Therefore, the peak of $\mathrm{SO}_{4}^{2-}$ at $0.65-1.1 \mu \mathrm{m}$ on Okinawa may be involved with aqueous-phase oxidation of $\mathrm{SO}_{2}$ in aerosols.

Size distribution of methanesulfonate $\left(\mathrm{MSA}^{-}\right)$is similar to that of $\mathrm{SO}_{4}^{2-}$ (Fig. 4i) on Okinawa. $\mathrm{MSA}^{-}$showed a strong correlation with $\mathrm{SO}_{4}^{2-}(r=0.89)$ in fine mode, suggesting that $\mathrm{MSA}^{-}$should have similar origin with $\mathrm{SO}_{4}^{2-}$ in fine mode. Although $\mathrm{MSA}^{-}$is produced by gas-to-particle conversion via the oxidation of dimethyl sulfide (DMS) emitted from the ocean (Quinn et al., 1993; Kerminen et al., 1997b), there is some indirect evidence that liquid-phase production might also be possible (Jefferson et al., 1998). Biomass burning also produces DMS in the atmosphere (Meinardi et al., 2003; Geng and $\mathrm{Mu}, 2006)$. $\mathrm{MSA}^{-}$showed high correlation with $\mathrm{K}^{+}$or $\mathrm{NH}_{4}^{+}(r=0.92)$ in fine mode, indicating that an enhanced emission of DMS from biomass burning followed by the subsequent oxidation during long-range transport may have contributed significantly to fine-mode $\mathrm{MSA}^{-}$on Okinawa. Moreover, $\mathrm{MSA}^{-}$can also be produced in fine mode by the oxidation of DMS that is emitted from marine phytoplankton in the surrounding ocean. It is noteworthy that East Asian aerosols traveled over the marine regions including the East China Sea, Sea of Japan, and Pacific Ocean during long-range atmospheric transport. The size distribution of $\mathrm{MSA}^{-}$observed over Okinawa is consistent with previous studies from the China Sea by Gao et al. (1996), who suggested that MSA is produced through the oxidation of Scontaining species in the marine atmosphere.

$\mathrm{NH}_{4}^{+}$in the Okinawa aerosols shows a unimodal size distribution with a peak at $0.65-1.1 \mu \mathrm{m}$ (Fig. $4 \mathrm{~h}$ ), indicating that $\mathrm{NH}_{4}^{+}$is mainly formed by gas-to-particle conversion via the reaction with $\mathrm{H}_{2} \mathrm{SO}_{4}$ and $\mathrm{HNO}_{3}$. Interestingly, the size distribution of $\mathrm{NH}_{4}^{+}$is similar to that of $\mathrm{SO}_{4}^{2-}$ and diacids such as oxalic acid (Figs. $4 \mathrm{~g}$ and $5 \mathrm{a}$ ). We also found a strong correlation between $\mathrm{SO}_{4}^{2-}$ and $\mathrm{NH}_{4}^{+}$on fine mode $(r=0.99)$. Ion balance calculations are commonly used to evaluate acidbase balance of aerosol particles. Average equivalent ratios of total cations $\left(\mathrm{Na}^{+}, \mathrm{NH}_{4}^{+}, \mathrm{K}^{+}, \mathrm{Mg}^{2+}\right.$, and $\left.\mathrm{Ca}^{2+}\right)$ to anions $\left(\mathrm{Cl}^{-}, \mathrm{NO}_{3}^{-}\right.$, and $\left.\mathrm{SO}_{4}^{2-}\right)$ in fine fractions varied from 0.75 for the size bin of $0.65-1.1 \mu \mathrm{m}$ to 0.86 for the size bin of 1.1$2.1 \mu \mathrm{m}$, indicating that fine-mode aerosols on Okinawa were apparently acidic.

$\mathrm{NH}_{3}$ is an alkaline gas that neutralizes the acidic particles in the atmosphere. Kerminen et al. (1997a) proposed that particulate $\mathrm{NH}_{4}^{+}$is secondarily formed via heterogeneous reactions of gaseous $\mathrm{NH}_{3}$ with acidic species $\left(\mathrm{H}_{2} \mathrm{SO}_{4}\right.$ and $\mathrm{HNO}_{3}$ ). The reaction of $\mathrm{NH}_{3}$ with $\mathrm{H}_{2} \mathrm{SO}_{4}$ is favored over its reaction with $\mathrm{HNO}_{3}$. The average $\mathrm{NH}_{4}^{+} / \mathrm{SO}_{4}^{2-}$ equivalent ratios in fine-mode particles on Okinawa varied from 0.36 for the size bin of $1.1-2.1 \mu \mathrm{m}$ to 0.81 for the size bin of $0.43-$ 

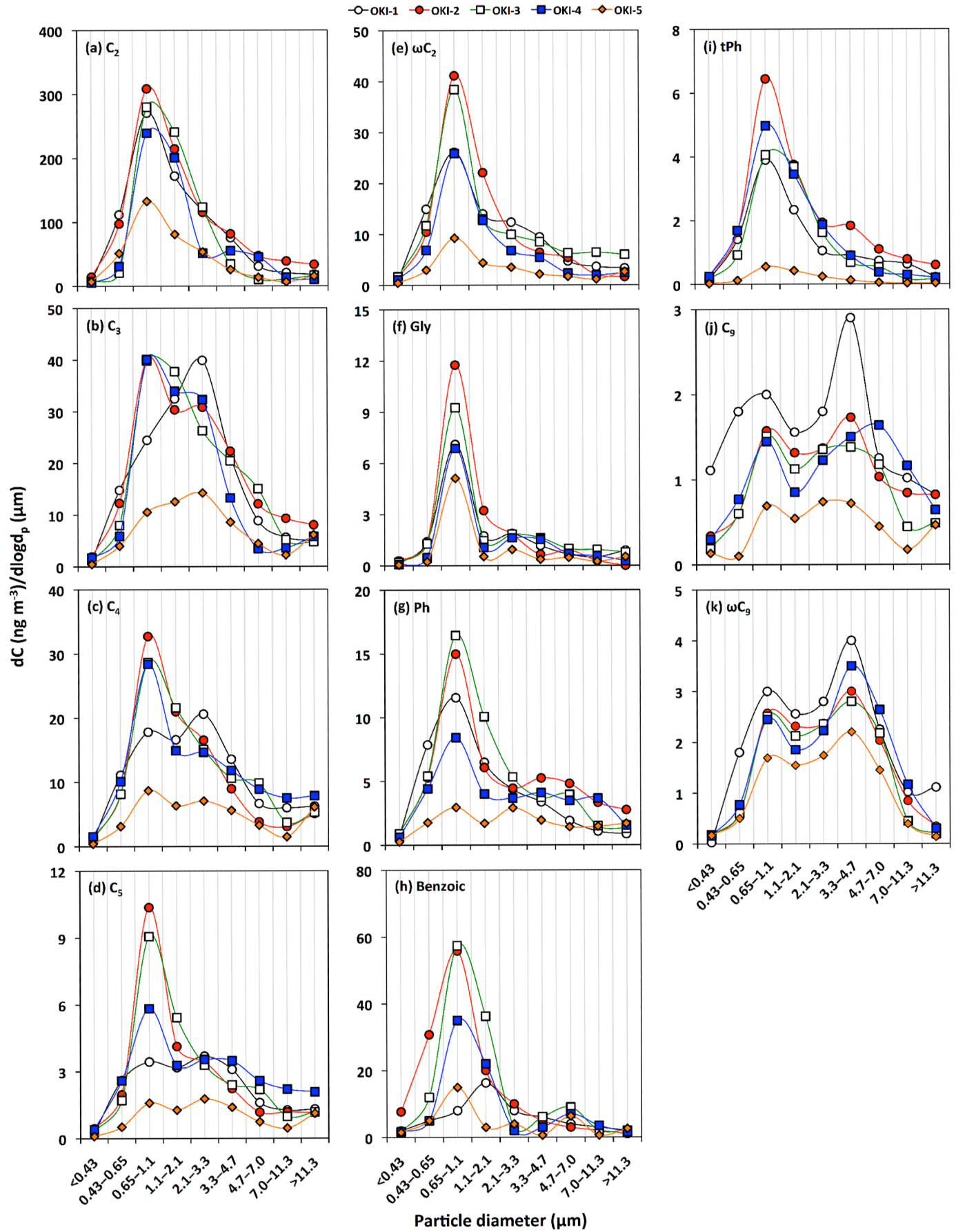

Figure 5. Size distributions of selected water-soluble dicarboxylic acids and related compounds in the aerosol samples collected on Okinawa Island.

$0.65 \mu \mathrm{m}$, indicating that $\mathrm{NH}_{3}$ was not abundant enough to neutralize all $\mathrm{SO}_{2}$. The aerosol chemical composition data obtained from the ISORROPIA II model revealed that significant amounts of $\mathrm{SO}_{4}^{2-}, \mathrm{HSO}_{4}^{-}$, and $\mathrm{NH}_{4}^{+}$in fine mode were present in liquid phase, whereas $\mathrm{SO}_{4}^{2-}$ and $\mathrm{NO}_{3}^{-}$were mainly present as solid phase in the coarse-mode aerosols in the forms of $\mathrm{CaSO}_{4}$ and $\mathrm{Ca}\left(\mathrm{NO}_{3}\right)_{2}$, respectively. Interest- ingly, the average $\mathrm{NH}_{4}^{+} / \mathrm{SO}_{4}^{2-}$ equivalent ratios in coarsemode particles ranged from 0.01 for the size bin $>11.3 \mu \mathrm{m}$ to 0.09 for the size bins of $2.1-3.3$ and $3.3-4.7 \mu \mathrm{m}$, suggesting that coarse-mode aerosols on Okinawa were also $\mathrm{NH}_{4}^{+}$-poor. This result further indicates that there was not enough $\mathrm{NH}_{3}$ to neutralize $\mathrm{HNO}_{3}$, and thus the shortfall of $\mathrm{NH}_{3}$ may be the restrictive factor for the formation of $\mathrm{NH}_{4} \mathrm{NO}_{3}$ in Oki- 
nawa aerosols. Therefore, $\mathrm{NO}_{3}^{-}$reacts with coarse particles that contain alkaline species $\left(\mathrm{Ca}^{2+}\right)$ in Okinawa aerosols.

The size distribution of $\mathrm{SO}_{4}^{2-}$ depends on the concentration of $\mathrm{NH}_{4}^{+}$, richness of $\mathrm{NH}_{3}$ in the air, and the presence of coarse-mode particles. $\mathrm{SO}_{4}^{2-}$ and $\mathrm{NH}_{4}^{+}$often coexist in fine mode because $\mathrm{H}_{2} \mathrm{SO}_{4}$ condenses on this mode as fine particles that have more surface area (Jacobson, 2002). Although $\mathrm{NH}_{3}$ was not abundant enough to neutralize all $\mathrm{SO}_{4}^{2-}$, most of $\mathrm{SO}_{4}^{2-}$ might be neutralized by $\mathrm{NH}_{3}$ in fine mode. Hence, $\mathrm{SO}_{4}^{2-}$ is enriched in fine mode rather than being associated with dust particles. An enrichment of $\mathrm{NO}_{3}^{-}$in the dust fraction in our study is supported by the laboratory studies of Hanisch and Crowley (2001a, b), who found a large and irreversible uptake between $\mathrm{HNO}_{3}$ and various authentic dust samples including samples from the Chinese dust region.

\subsection{Water-soluble organic carbon (WSOC) and organic carbon (OC)}

The mass-based size distribution of WSOC is characterized by a major peak at $0.65-1.1 \mu \mathrm{m}$ in fine mode and by a small peak at 3.3-4.7 $\mu \mathrm{m}$ in coarse mode (Fig. 6a and Table 1). Huang et al. (2006) observed that fine-mode WSOC was primarily derived from combustion sources and secondarily produced in the atmosphere by the photochemical oxidation of VOCs. The WSOC concentrations showed a strong correlation with fine-mode $\mathrm{SO}_{4}^{2-}(r=0.96)$. Because production of $\mathrm{SO}_{4}^{2-}$ is closely linked to photochemical activity, this result suggests an important secondary production of WSOC in fine-mode particles during long-range atmospheric transport from East Asia. WSOC concentrations also showed high correlation with $\mathrm{K}^{+}(r=0.93)$ and $\mathrm{NH}_{4}^{+}(r=0.91)$ in fine mode. This result suggests that direct emission from biomass burning or fast oxidation of biomass-burning-derived precursors significantly contributes to the formation of fine-mode WSOC in Okinawa aerosols during long-range transport.

The mass size distribution pattern of $\mathrm{OC}$ is similar to that of WSOC with a major peak in the size range of $0.65-1.1 \mu \mathrm{m}$, whereas a small peak appeared in the size range of 3.3$4.7 \mu \mathrm{m}$ in diameter (Fig. 6b). Primary emission from biomass burning and/or photooxidation of biomass-burning-derived precursors might be a dominant source of fine-mode OC in Okinawa aerosols. This interpretation is supported by the fact that $\mathrm{OC}$ showed a strong correlation $(r=0.95)$ with $\mathrm{K}^{+}$in fine mode. The fine-mode $\mathrm{OC}$ showed significant positive correlations with $\mathrm{SO}_{4}^{2-}(r=0.93)$ and $\mathrm{NH}_{4}^{+}(0.91)$, suggesting a secondary photochemical formation of $\mathrm{OC}$ in the fine mode of Okinawa aerosols.

A significant portion of OC may be oxidized to WSOC during the atmospheric transport from East Asia to the western North Pacific. The mass ratio of WSOC / OC has been proposed as a measure of photochemical processing or aging of organic aerosols especially in long-range-transported aerosols (Aggarwal and Kawamura, 2009). The WSOC / OC

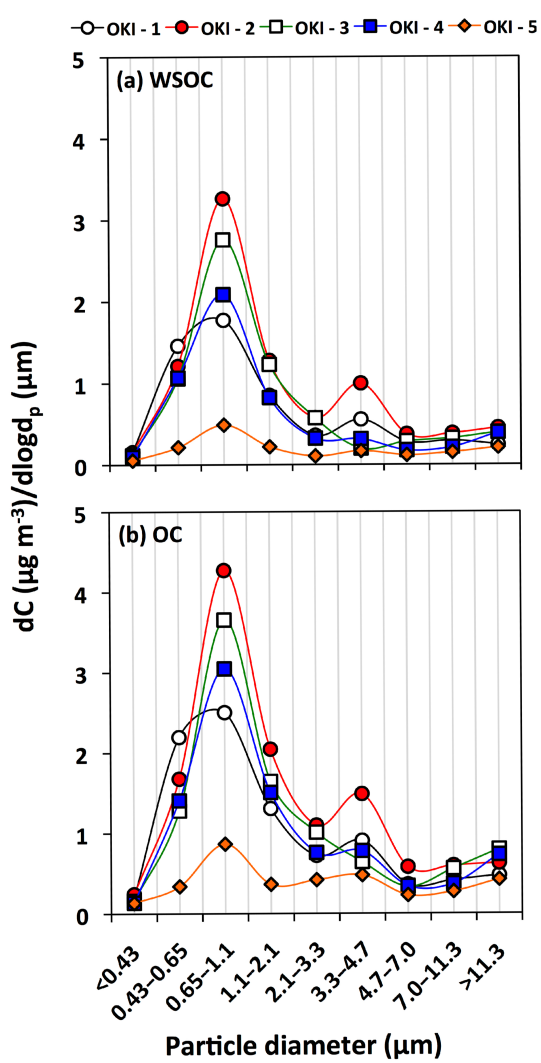

Figure 6. Size distributions of water-soluble organic carbon (WSOC) and organic carbon (OC) in the aerosol samples collected on Okinawa Island.

ratios varied from 0.51 to 0.76 with an average of $0.67 \pm 0.09$ in the fine mode and from 0.43 to 0.63 with an average of $0.55 \pm 0.09$ in the coarse mode. The higher WSOC / OC ratio in fine mode suggests that organics are significantly subjected to photochemical processing in fine aerosols during long-range transport from the Asian continent to Okinawa compared to coarse-mode aerosols.

Source contributions and secondary processes that may convert VOCs to more soluble forms on the surface area of fine particles could cause higher WSOC / OC ratios in fine mode. Biomass-burning-derived $\mathrm{OC}$ is highly watersoluble and usually resides in fine mode, whereas coarsemode OC contains high molecular weight organic compounds emitted by soil resuspension and emissions of pollen and fungal spores, which are less water-soluble (Wang et al., 2011; Mkoma et al., 2013). Biomass burning significantly contributed to fine-mode WSOC on Okinawa as discussed above. Moreover, accumulation of gas-phase precursors of WSOC may occur preferentially in the particle size, with the greatest surface area (Kanakidou et al., 2005). It has been proposed that fine particles offer more surface area, and thus the reaction rate is more on the surface of fine particles than coarse particles (Kanakidou et al., 2005). The higher WSOC / OC ratio in fine particles than coarse parti- 
cles has also been observed in long-range-transported East Asian aerosols over northern Japan (Agarwal et al., 2010).

The WSOC/OC ratio in fine mode showed a weak positive correlation with downward solar radiation flux $(r=0.39)$. This weak correlation is probably due to the fact that fine-mode WSOC can be produced in the aqueous phase of aerosols during long-range transport. Based on the yearround measurements of total suspended aerosols from Okinawa Island, Kunwar and Kawamura (2014) documented higher WSOC / OC ratio in winter (ave. 0.60) and spring (ave. 0.45) than summer (ave. 0.28). These observations demonstrate that WSOC can be produced from OC under a weak solar radiation condition on the transport pathway from the source region to Okinawa possibly via aqueous-phase processing.

Calculated LWC for each sample from Okinawa and average LWC in size-segregated aerosols are shown in Fig. 7. The highest LWC was found at the size of $0.65-1.1 \mu \mathrm{m}$ in the fine mode in Okinawa samples. WSOC can also contribute to aerosol LWC, although its ability to absorb water is significantly less than that of inorganics (Ansari and Pandis, 2000; Speer et al., 2003; Engelhart et al., 2011). Moreover, organic species are not taken into account in ISORROPIA II for the calculation of LWC. It is noteworthy that WSOC / OC ratio and LWC in fine mode significantly correlate with $r=0.87$, whereas negative correlation was found in coarse mode $(r=-0.19)$, suggesting a possible production of WSOC from OC in aerosol aqueous phase in the fine mode of Okinawa aerosols. There may also be another important source of fine-mode WSOC in Okinawa aerosols such as primary emission from biomass burning and secondary formation via gas-phase photochemical reactions during longrange atmospheric transport (Hagler et al., 2007; Lim et al., 2010). This result may indicate that shorter-chain diacids and related polar compounds can contribute more to fine-mode WSOC via oxidation of various organic precursors during long-range transport (Carlton et al., 2007; Kawamura et al., 2005, 2007; Miyazaki et al., 2010).

\subsection{Dicarboxylic acids and related compounds}

The size distributions of selected diacids and related compounds are shown in Fig. 5. Based on the sources and formation processes, their size distributions fall into two groups: a group with a dominant fine mode and a group with a dominant coarse mode, as discussed in the following sections.

\subsection{1 $\mathrm{C}_{2}, \omega \mathrm{C}_{2}$, Gly, Ph, and benzoic acid}

The first group, including $\mathrm{C}_{2}, \omega \mathrm{C}_{2}, \mathrm{Gly}, \mathrm{Ph}$, and benzoic acid, showed similar size distributions to maxima in fine mode. $\mathrm{C}_{2}$ showed a peak at $0.65-1.1 \mu \mathrm{m}$ in fine mode (Fig. 5a). The size distribution of $\mathrm{C}_{2}$ on Okinawa is different from that observed off the coast of East Asia by Mochida et al. (2003a, 2007), who found a strong bimodal pattern of

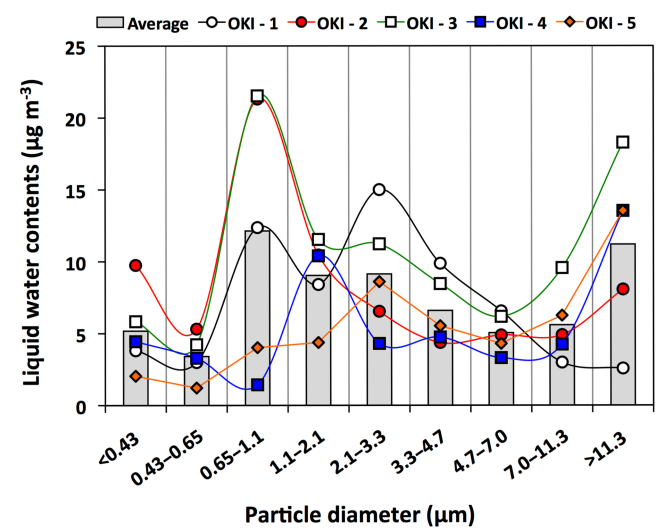

Figure 7. Aerosol liquid water contents for each sample in sizesegregated aerosols and average liquid water contents in sizesegregated aerosols on Okinawa Island.

$\mathrm{C}_{2}$ with a peak in the coarse mode. They suggested that the coarse-mode peak of $\mathrm{C}_{2}$ emerged by the uptake of gaseous diacids or heterogeneous oxidations of organic precursors on the dust and sea salt particles during long-range transport. The unimodal distribution of $\mathrm{C}_{2}$ on Okinawa with maxima in fine mode suggests that the heterogeneous uptake of $\mathrm{C}_{2}$ on dust and sea salt particles did not occur.

The condensation mode of $\mathrm{C}_{2}$ is likely produced photochemically in the gas phase followed by condensation onto preexisting particles at $0.1-0.5 \mu \mathrm{m}$ (Huang et al., 2006). The fine-mode peak of $\mathrm{C}_{2}$ at the size of $0.65-1.1 \mu \mathrm{m}$ in Okinawa aerosols suggests a preferential production of $\mathrm{C}_{2}$ via the oxidation of precursors in aerosol aqueous phase during long-range atmospheric transport. We found that size distribution of $\mathrm{C}_{2}$ diacid is similar to that of $\mathrm{SO}_{4}^{2-}$ (Figs. $4 \mathrm{~g}$ and 5a), suggesting a secondary formation of $\mathrm{C}_{2}$, possibly in aerosol aqueous phase. The good correlations of $\mathrm{C}_{2}$ with $\mathrm{SO}_{4}^{2-}(r=0.92)$ and $\mathrm{NH}_{4}^{+}(0.89)$ in fine mode further supports that $\mathrm{C}_{2}$ is a secondary photochemical product. Finemode $\mathrm{C}_{2}$ can also be produced primarily from fossil fuel combustion and biomass burning in East Asia and longrange-transported to Okinawa. $\mathrm{C}_{2}$ diacid showed a significant positive correlation with fine-mode $\mathrm{K}^{+}(r=0.85)$, indicating that biomass burning contributed significantly to fine-mode $\mathrm{C}_{2}$ in Okinawa aerosols.

Lim et al. (2005) and Legrand et al. (2007) reported the formation of diacids in aqueous phase. Here we investigate the impact of LWC on the formation of diacids in Okinawa aerosols. LWC of a particle can influence the production of $\mathrm{C}_{2}$ via the changes in gas/particle partitioning of organic precursors and subsequent heterogeneous reactions in aerosol aqueous phase. A strong positive correlation $(r=0.92)$ of $\mathrm{C}_{2}$ with LWC was found in fine mode, whereas the correlation was negative in coarse mode $(r=-0.29)$, indicating a possible aqueous-phase production of $\mathrm{C}_{2}$ via the oxidation of $\mathrm{C}_{2}$ precursors in fine mode. Several secondary for- 
mation pathways are known to $\mathrm{C}_{2}$ in atmospheric aerosols. $\mathrm{C}_{2}$ is produced by the decay of its higher homologues $\left(\mathrm{C}_{3}-\right.$ $\mathrm{C}_{5}$ diacids) or oxidation of unsaturated fatty acids such as oleic acid $\left(\mathrm{C}_{18: 1}\right)$ followed by the degradation to shorterchain diacids in aqueous phase (Kawamura and Ikushima, 1993; Kawamura and Sakaguchi, 1999; Pavuluri et al., 2015). $\mathrm{C}_{2}$ can also be produced by the aqueous-phase oxidation of $\omega \mathrm{C}_{2}$, which can be formed by aqueous oxidation of Gly and MeGly, produced by the oxidation of various VOCs including toluene, ethene, and isoprene (Zimmermann and Poppe, 1996; Volkamer et al., 2001; Lim et al., 2005; Carlton et al., 2006; Ervens et al., 2008).

The scatter plots of $\mathrm{C}_{2}$ with $\mathrm{C}_{3}-\mathrm{C}_{5}$ diacids in fine and coarse modes are shown in Fig. S3. The robust correlations of $\mathrm{C}_{2}$ with $\mathrm{C}_{3}-\mathrm{C}_{5}$ diacids $(r=0.89-0.92)$ were found in fine mode, indicating that they might have similar sources and origin or $\mathrm{C}_{2}$ may be produced via the decay of its higher homologues $\left(\mathrm{C}_{3}-\mathrm{C}_{5}\right.$ diacids $)$ during long-range transport. The differences in the slopes of linear regression of $\mathrm{C}_{2}$ with $\mathrm{C}_{3}$ and $\mathrm{C}_{4}$ diacids between fine and coarse modes are not significant but slopes are slightly higher in fine mode than the coarse mode (Fig. S3a-d and Table S1). Interestingly, a significantly higher slope was observed for the regression line between $\mathrm{C}_{2}$ and glutaric $\left(\mathrm{C}_{5}\right)$ acid in fine mode than coarse mode (Fig. S3e-f and Table S1). It is also noteworthy that the slope of the regression line of $\mathrm{C}_{2}$ with $\mathrm{C}_{5}$ diacid is significantly higher than that for $\mathrm{C}_{3}$ and $\mathrm{C}_{4}$ diacids in fine mode (Fig. S3a, c, e and Table S2). These results indicate that finemode oxalic acid may be produced from oxidation of glutaric acid during long-range transport via succinic and malonic acids as intermediates. The laboratory studies of Hatakeyama et al. (1985) and Kalberer et al. (2010) have documented that glutaric acid is produced by the oxidation of cyclohexene by $\mathrm{O}_{3}$, which can be further oxidized in aqueous phase to result in oxalic acid (Kawamura and Sakaguchi, 1999; Legrand et al., 2007). This interpretation is further supported by the fact that $\mathrm{C}_{3}-\mathrm{C}_{5}$ diacids were enriched in the fine mode of most samples (Fig. 5b-d) and showed good correlations with LWC ( $r=0.82-0.89$ ), possibly due to the enhanced secondary production by the oxidation of its precursor compounds in aerosol aqueous phase.

The size distribution of $\omega \mathrm{C}_{2}$ and Gly is similar to that of $\mathrm{C}_{2}$ diacid in the Okinawa samples (Fig. 5e and f). The enrichment of $\omega \mathrm{C}_{2}$ and Gly in fine mode may be associated with enhanced secondary formation via aqueous-phase processing of their precursors during long-range transport. This interpretation is evidenced by the fact that strong correlations of $\omega \mathrm{C}_{2}$ and Gly were found with $\mathrm{SO}_{4}^{2-}(r=0.96$ and 0.86 , respectively) and LWC (0.95) in fine mode. The fine-mode $\omega \mathrm{C}_{2}$ and Gly can also be produced primarily from biomass burning in East Asia and be long-range-transported to Okinawa. Significant positive correlations between $\omega \mathrm{C}_{2}$ and $\mathrm{K}^{+}$ $(r=0.90)$, and Gly and $\mathrm{K}^{+}(0.86)$ suggest that biomass burning contributed significantly to the fine-mode $\omega \mathrm{C}_{2}$ and Gly in Okinawa aerosols. Gly is a well-known precursor of $\omega \mathrm{C}_{2}$ and $\mathrm{C}_{2}$ in atmospheric aerosols (Lim et al., 2005; Ervens and Volkamer, 2010; Myriokefalitakis et al., 2011). The preferential enrichment of Gly and $\omega \mathrm{C}_{2}$ in fine mode can form $\mathrm{C}_{2}$ in Okinawa aerosols by aqueous-phase processing.

High correlations among $\mathrm{C}_{2}, \omega \mathrm{C}_{2}$, and Gly in fine mode $(r=0.92-0.99)$ also indicate their similar sources and formation processes and that $\mathrm{C}_{2}$ diacid may be produced by the oxidation of $\omega \mathrm{C}_{2}$ and Gly in fine mode. There is no significant difference in the slope of regression line of $\mathrm{C}_{2}$ with $\omega \mathrm{C}_{2}$ between the fine and coarse modes (Fig. S3g-h and Table $\mathrm{S} 1$ ), whereas the slope of the regression line of $\mathrm{C}_{2}$ with Gly is significantly higher in fine mode than coarse mode (Fig. S3i-j and Table S1). It is also remarkable that the slope of linear regression of $\mathrm{C}_{2}$ with Gly is significantly higher than that with $\omega \mathrm{C}_{2}$ in fine mode (Fig. S3g-i and Table S2). This result may indicate a possible formation of fine-mode oxalic acid from glyoxal via glyoxylic acid as an intermediate during long-range atmospheric transport in the western North Pacific.

The enrichment of $\mathrm{C}_{2}, \omega \mathrm{C}_{2}$, and Gly in fine mode on Okinawa was probably due to the enhanced oxidation of anthropogenic precursors emitted in East Asia during long-range transport because their size distributions are consistent with that of $\mathrm{Ph}$ and benzoic acid (Fig. 5g and h), which are tracers of anthropogenic sources. The strong correlations of finemode $\mathrm{C}_{2}, \omega \mathrm{C}_{2}$, and Gly with $\mathrm{Ph}(r=0.85-0.93)$ and benzoic acid ( $r=0.90-0.96)$ further suggest that anthropogenic precursors are their important sources in fine mode. Ph and benzoic acid are directly emitted from combustion sources and secondarily produced in the atmosphere by the photooxidation of aromatic hydrocarbons emitted from the incomplete combustion of fossil fuel (Kawamura et al., 1985; Kawamura and Kaplan, 1987; Ho et al., 2006).

Aromatic hydrocarbons such as naphthalene and toluene have been suggested as major precursors of $\mathrm{Ph}$ and benzoic acid, respectively (Schauer et al., 1996; Kawamura and Yasui, 2005). Based on the high levels of naphthalene and toluene in China (Liu et al., 2007; Tao et al., 2007; Duan et al., 2008), Ho et al. (2015) recently suggested that oxidation of naphthalene and toluene in the atmosphere is one of the major sources of $\mathrm{Ph}$ and benzoic acid, respectively. High levels of precursors in the source regions might favor the significant secondary production of $\mathrm{Ph}$ and benzoic acid during long-range transport in the western North Pacific. It may be possible that their precursors emitted in East Asia were taken up by aqueous-phase aerosol and oxidized to result in $\mathrm{Ph}$ and benzoic acid in fine mode during long-range transport. Moreover, enrichment of $\mathrm{Ph}$ and benzoic acid in fine mode further suggests that these species are associated with combustion sources either by primary emission and/or secondary production from the precursor compounds, being consistent with other anthropogenic $\mathrm{SO}_{4}^{2-}, \mathrm{NH}_{4}^{+}$, and $\mathrm{K}^{+}$. Fine-mode $\mathrm{Ph}$ can also be produced from evaporation of phthalates from plastics used in populated and industrialized regions in East Asia and long-range-transported to Okinawa 
as discussed earlier. This explanation is consistent with the enrichment of terephthalic acid (tPh) in fine mode (Fig. 5i), which is a tracer of plastic burning (Kawamura and Pavuluri, 2011).

\subsection{2 $\mathrm{C}_{9}$ and $\omega \mathrm{C}_{9}$}

The second group of organic compounds, including $\mathrm{C}_{9}$ and $\omega \mathrm{C}_{9}$, showed bimodal size distribution with a major peak on coarse mode at 3.3-4.7 $\mu \mathrm{m}$ and minor peak on fine mode at $0.65-1.1 \mu \mathrm{m}$ (Fig. $5 \mathrm{j}$ and k). The strong correlations were found between $\mathrm{C}_{9}$ and $\mathrm{Na}^{+}(r=0.85)$, and $\omega \mathrm{C}_{9}$ and $\mathrm{Na}^{+}$ (0.83) in coarse mode, indicating that $\mathrm{C}_{9}$ and $\omega \mathrm{C}_{9}$ may be emitted into the atmosphere from the sea surface microlayers together with sea salt particles on Okinawa. Kawamura and Gagosian (1987) suggested that $\mathrm{C}_{9}$ and $\omega \mathrm{C}_{9}$ are also derived from the photooxidation of unsaturated fatty acids such as oleic acid $\left(\mathrm{C}_{18: 1}\right)$ that are produced by phytoplankton and emitted from sea surface microlayers as sea salt particles. The laboratory experiments also documented the formation of $\mathrm{C}_{9}$ and $\omega \mathrm{C}_{9}$ due to photooxidation of $\mathrm{C}_{18: 1}$ (Matsunaga et al., 1999; Huang et al., 2005; Ziemann, 2005; Tedetti et al., 2007). Sea surface microlayers in the surroundings of Okinawa can also emit unsaturated fatty acids together with sea salts. Therefore, the major peaks of $\mathrm{C}_{9}$ and $\omega \mathrm{C}_{9}$ on the coarse mode may be derived from heterogeneous oxidation of unsaturated fatty acids of marine phytoplankton origin on the sea salt particles.

Wang et al. (2011) suggested that unsaturated fatty acids can be directly emitted as fine particles from food cooking emissions in urban areas in China and be oxidized to $\mathrm{C}_{9}$ diacid in fine mode. The minor peak of $\mathrm{C}_{9}$ and $\omega \mathrm{C}_{9}$ in fine mode can be explained by the oxidation of fine-mode unsaturated fatty acids derived from food cooking or gaseous unsaturated fatty acids during long-range transport to the western North Pacific.

\subsection{Ratios of selected diacids}

Kawamura and Ikushima (1993) proposed that the malonic to succinic acid ratio $\left(\mathrm{C}_{3} / \mathrm{C}_{4}\right)$ is a tracer to evaluate the extent of photochemical processing of organic aerosols. Because $\mathrm{C}_{4}$ is oxidized to $C_{3}$, an increase in the $C_{3} / C_{4}$ ratio indicates an increased photochemical processing. The average $\mathrm{C}_{3} / \mathrm{C}_{4}$ ratio in sum of all the size fractions was found to be $1.5 \pm 0.1$ in Okinawa aerosols. This result suggests that the extent of photochemical processing is much greater on Okinawa than Los Angeles (0.35) (Kawamura and Kaplan, 1987) but similar to that of urban Tokyo (1.5) (Kawamura and Ikushima, 1993), whereas it is lower than those of marine aerosols at Chichijima Island in the western North Pacific (2.0) (Mochida et al., 2003b) and the remote Pacific including the tropics (3.9) (Kawamura and Sakaguchi, 1999). Figure 8a shows changes in the $C_{3} / C_{4}$ ratios as a function of particle size. The $C_{3} / C_{4}$ ratios exhibit higher values at $1.1-2.1 \mu \mathrm{m}$ in fine mode and at

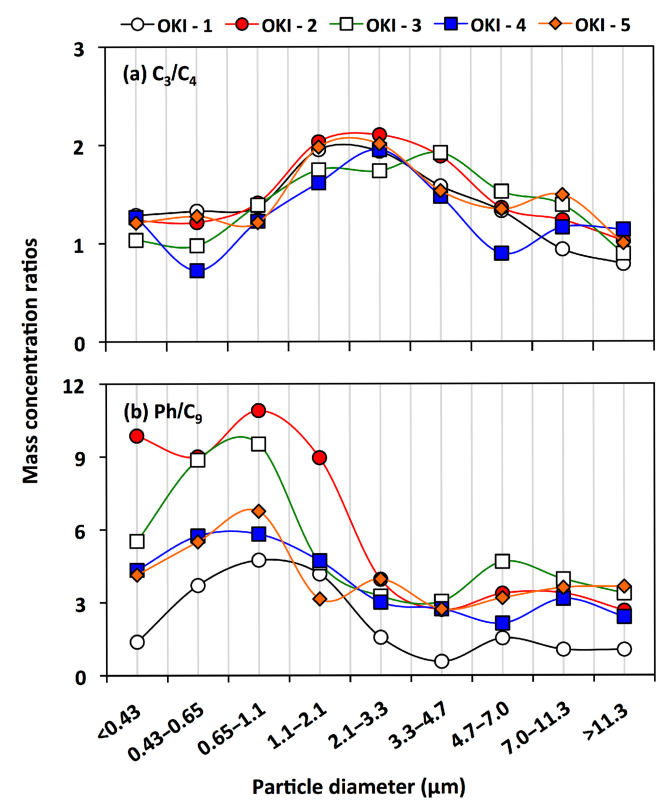

Figure 8. Mass concentration ratios of malonic to succinic acid and phthalic to azelaic acid in size-segregated aerosols collected on Okinawa Island.

2.1-3.3 and 3.3-4.7 $\mu \mathrm{m}$ in coarse mode. This result suggests that $\mathrm{C}_{3}$ production via $\mathrm{C}_{4}$ decomposition occurs more efficiently at these size ranges by aqueous-phase processing.

$\mathrm{Ph}$ diacid originates from various anthropogenic sources, whereas $\mathrm{C}_{9}$ diacid is specifically produced by the oxidation of biogenic unsaturated fatty acids (Kawamura and Gagosian, 1987; Kawamura and Ikushima, 1993). Therefore, $\mathrm{Ph} / \mathrm{C}_{9}$ ratio is most likely used as a tracer to understand the source strength of anthropogenic vs. biogenic sources of diacids. A higher $\mathrm{Ph} / \mathrm{C}_{9}$ ratio shows more influence of anthropogenic sources, whereas a lower ratio shows more influence of biogenic sources. Figure $8 \mathrm{~b}$ presents changes in the ratios of $\mathrm{Ph} / \mathrm{C}_{9}$ as a function of particle sizes. The higher $\mathrm{Ph} / \mathrm{C}_{9}$ ratios were obtained on fine-mode particles rather than coarse-mode particles. These results suggest that fine aerosols on Okinawa are significantly influenced by anthropogenic sources whereas the coarse aerosols are more influenced by biogenic sources. A significant contribution of $\mathrm{Ph}$ on fine mode further supports that anthropogenic sources are an important source of diacids and related compounds in the fine mode of Okinawa aerosols.

\section{Summary and conclusions}

Nine-stage atmospheric particles from $<0.43$ to $>11.3 \mu \mathrm{m}$ in diameter, collected in spring 2008 at Cape Hedo, Okinawa, in the western North Pacific Rim, were analyzed for watersoluble diacids and related compounds as well as watersoluble organic carbon (WSOC), organic carbon (OC), and inorganic ions. The molecular distributions of diacids were 
characterized by the predominance of oxalic acid $\left(\mathrm{C}_{2}\right)$ followed by malonic $\left(\mathrm{C}_{3}\right)$ and succinic $\left(\mathrm{C}_{4}\right)$ acids in all stages, suggesting that they are most likely produced by the photooxidation of VOCs and particulate organic precursors in the source region and/or during long-range atmospheric transport. The abundant presence of $\mathrm{SO}_{4}^{2-}$ as well as phthalic and adipic acids in Cape Hedo suggested a significant contribution of anthropogenic sources including industrial emissions in East Asia to Okinawa aerosols via long-range atmospheric transport.

$\mathrm{SO}_{4}^{2-}, \mathrm{NH}_{4}^{+}$, and diacids up to 5-carbon atoms as well as glyoxylic acid $\left(\omega \mathrm{C}_{2}\right)$ and glyoxal (Gly) showed good correlations with peaks in fine mode $(0.65-1.1 \mu \mathrm{m})$. WSOC and OC also peaked on fine mode with an additional minor peak on coarse mode. Similar size distributions and strong correlations of diacids $\left(\mathrm{C}_{2}-\mathrm{C}_{5}\right), \omega \mathrm{C}_{2}$ and Gly with $\mathrm{SO}_{4}^{2-}$ in fine mode suggest their secondary formation possibly in aerosol aqueous phase. Their strong correlations with LWC in fine mode further suggest an importance of the aqueous-phase production in Okinawa aerosols. They may have also been directly emitted from biomass burning as supported by strong correlations with $\mathrm{K}^{+}$in fine mode. The robust correlations of $\mathrm{C}_{2}$ with $\mathrm{C}_{3}-\mathrm{C}_{5}$ diacids as well as $\omega \mathrm{C}_{2}$ and Gly indicate that they are the key precursors of $\mathrm{C}_{2}$ diacid in Okinawa aerosols.

Longer-chain diacid $\left(\mathrm{C}_{9}\right)$ and $\omega$-oxoacid $\left(\omega \mathrm{C}_{9}\right)$ showed bimodal size distribution with a major peak on coarse mode, suggesting that they were directly emitted and/or produced by photooxidation of unsaturated fatty acids mainly derived from sea surface microlayers via heterogeneous reactions on sea spray particles. We observed that WSOC and OC in fine particles are photochemically more processed in the atmosphere than in coarse particles during long-range transport. This study demonstrates that anthropogenic and biomass burning aerosols emitted from East Asia have significant influence on the molecular compositions of water-soluble organic aerosols in the western North Pacific Rim.

\section{Data availability}

The data from this paper can be obtained by contacting the authors of this article.

Meteorological data including ambient temperature, relative humidity, and wind speed for each sample period were obtained from the Japan Meteorological Agency (http: //www.jma.go.jp).

\section{The Supplement related to this article is available online at doi:10.5194/acp-16-5263-2016-supplement.}

Acknowledgements. We acknowledge the financial support from the Japan Society for the Promotion of Science (JSPS) through grants-in-aid nos. 1920405 and 24221001. We appreciate the financial support of the JSPS fellowship to D. K. Deshmukh. We also acknowledge the support of ENSCR to M. Lazaar for the summer student program in Japan. The authors gratefully appreciate the NOAA Air Resources Laboratory (ARL) for the provision of the HYSPLIT transport and dispersion model (http://www.ready.noaa.gov) for 7-day air mass backward trajectories of sampling site Cape Hedo for each sampling period. We thank E. Tachibana for the analyses of OKI-5 samples, and M. Mochida, S. Aggarwal, and Y. Kitamori for their help during the campaign. The authors appreciate the critical and useful comments by anonymous reviewers, which significantly improved the quality of the manuscript.

Edited by: V.-M. Kerminen

\section{References}

Agarwal, S., Aggarwal, S. G., Okuzawa, K., and Kawamura, K.: Size distributions of dicarboxylic acids, ketoacids, a-dicarbonyls, sugars, WSOC, OC, EC and inorganic ions in atmospheric particles over Northern Japan: implication for long-range transport of Siberian biomass burning and East Asian polluted aerosols, Atmos. Chem. Phys., 10, 5839-5858, doi:10.5194/acp-10-58392010, 2010.

Aggarwal, S. G. and Kawamura, K.: Carbonaceous and inorganic composition in long-range transported aerosols over northern Japan: implicationsn for aging of water-soluble organic fraction, Atmos. Environ., 43, 2532-2540, 2009.

Andreas, E. L.: A new sea spray generation function for wind speeds up to $32 \mathrm{~m} \mathrm{~s}^{-1}$, J. Phys. Oceanogr., 28, 2175-2184, 1998.

Ansari, A. S. and Pandis, S. N.: Water absorption by secondary organic aerosol and its effect on inorganic aerosol behavior, Environ. Sci. Technol., 34, 71-77, 2000.

Bian, Q., Huang, X. H. H., and Yu, J. Z.: One-year observations of size distribution characteristics of major aerosol constituents at a coastal receptor site in Hong Kong - Part 1: Inorganic ions and oxalate, Atmos. Chem. Phys., 14, 9013-9027, doi:10.5194/acp14-9013-2014, 2014.

Boreddy, S. K. R. and Kawamura, K.: A 12-year observation of water-soluble ions in TSP aerosols collected at a remote marine location in the western North Pacific: an outflow region of Asian dust, Atmos. Chem. Phys., 15, 6437-6453, doi:10.5194/acp-156437-2015, 2015.

Carlton, A. G., Turpin, B. J., Lim, H. J., Altieri, K. E., and Seitzinger, S.: Link between isoprene and secondary organic aerosol (SOA): Pyruvic acid oxidation yields low volatility organic acids in clouds, Geophys. Res. Lett., 33, L06822, doi:10.1029/2005GL025374, 2006.

Carlton, A. G., Turpin, B. J., Altieri, K. E., Seitzinger, S., Reff, A., Lim, H. J., and Ervens, B.: Atmospheric oxalic acid and SOA production from glyoxal: Results of aqueous photooxidation experiments, Atmos. Environ., 41, 7588-7602, 2007.

Davidson, C. I., Phalen, R. F., and Solomon, P. A.: Airborne particulate matter and human health: A review, Aerosol. Sci. Tech., 39, 737-749, 2005.

Draxler, R. R. and Rolph, G. D.: HYSPLIT (HYbrid Single-Particle Lagrangian Integrated Trajec- tory) Model, available at: http:// 
www.arl.noaa.gov/HYSPLIT.php (last access: 5 January 2015), NOAA Air Resouces Laboratory, College Park, MD, 2013.

Duan, J. C., Tan, J. H., Yang, L., Wu, S., and Hao, J. M.: Concentration, sources and ozone formation potential of volatile organic compounds (VOCs) during ozone episode in Beijing, Atmos. Res., 88, 25-35, 2008.

Engelhart, G. J., Hildebrandt, L., Kostenidou, E., Mihalopoulos, N., Donahue, N. M., and Pandis, S. N.: Water content of aged aerosol, Atmos. Chem. Phys., 11, 911-920, doi:10.5194/acp-11911-2011, 2011.

Engling, G., Lee, J. J., Sie, H. J., Wu, Y. C., and Yet-Pole, I.: Anhydrosugar characteristics in biomass smoke aerosol-case study of environmental influence on particle-size of rice straw burning aerosol, J. Aerosol Sci., 56, 2-14, 2013.

Ervens, B. and Volkamer, R.: Glyoxal processing by aerosol multiphase chemistry: towards a kinetic modeling framework of secondary organic aerosol formation in aqueous particles, Atmos. Chem. Phys., 10, 8219-8244, doi:10.5194/acp-10-8219-2010, 2010.

Ervens, B., Cubison, M., Andrews, E., Feingold, G., Ogren, J. A., Jimenez, J. L., DeCarlo, P., and Nenes, A.: Prediction of cloud condensation nucleus number concentration using measurements of aerosol size distributions and composition and light scattering enhancement due to humidity, J. Geophys. Res., 112, D10S32, doi:10.1029/2006jd007426, 2007.

Ervens, B., Carlton, A. G., Turpin, B. J., Altieri, K. E., Kreidenweis, S. M., and Feingold, G.: Secondary organic aerosol yields from cloud-processing of isoprene oxidation products, Geophys. Res. Lett., 35, L02816, doi:10.1029/2007gl031828, 2008.

Falkovich, A. H., Graber, E. R., Schkolnik, G., Rudich, Y., Maenhaut, W., and Artaxo, P.: Low molecular weight organic acids in aerosol particles from Rondônia, Brazil, during the biomassburning, transition and wet periods, Atmos. Chem. Phys., 5, 781797, doi:10.5194/acp-5-781-2005, 2005.

Fountoukis, C. and Nenes, A.: ISORROPIA II: a computationally efficient thermodynamic equilibrium model for $\mathrm{K}^{+}$. $\mathrm{Ca}^{2+}-\mathrm{Mg}^{2+}-\mathrm{NH}_{4}^{+}-\mathrm{Na}^{+}-\mathrm{SO}_{4}^{2-}-\mathrm{NO}_{3}^{-}-\mathrm{Cl}^{-}-\mathrm{H}_{2} \mathrm{O}$ aerosols, Atmos. Chem. Phys., 7, 4639-4659, doi:10.5194/acp-7-4639-2007, 2007

Gao, Y., Arimoto, R., Duce, R. A., Chen, L. Q., Zhou, M. Y., and Gu, D. Y.: Atmospheric non-sea-salt sulfate, nitrate and methanesulfonate over the China Sea, J. Geophys. Res., 101, 12601$12611,1996$.

Gao, X., Xue, L., Wang, X., Wang, T., Yuan, T., Gao, R., Zhou, Y., Nie, W., Zhang, Q., and Wang, W.: Aerosol ionic components at Mt. Heng in central southern China: abundances, size distribution, and impacts of long-range transport, Sci. Total Environ., 433, 498-506, 2012.

Geng, C. and Mu, Y: Carbonyl sulfide and dimethyl sulfide exchange between trees and the atmosphere, Atmos. Environ., 40, 1373-1383, 2006.

Geng, H., Park, Y., Hwang, H., Kang, S., and Ro, C.-U.: Elevated nitrogen-containing particles observed in Asian dust aerosol samples collected at the marine boundary layer of the Bohai Sea and the Yellow Sea, Atmos. Chem. Phys., 9, 6933-6947, doi:10.5194/acp-9-6933-2009, 2009.

Hagler, G. S. W., Bergin, M. H., Smith, E. A., and Dibb, J. E.: A summer time series of particulate carbon in the air and snow at Summit, Greenland, J. Geophys. Res., 112, D21309, doi:10.1029/2007JD008993, 2007.

Hanisch, F. and Crowley, J. N.: Heterogeneous reactivity of gaseous nitric acid on $\mathrm{Al}_{2} \mathrm{O}_{3}, \mathrm{CaCO}_{3}$, and atmospheric dust samples: $\mathrm{A}$ Knudsen cell study, J. Phys.Chem. A, 105, 3096-3106, 2001a.

Hanisch, F. and Crowley, J. N.: The heterogeneous reactivity of gaseous nitric acid on authentic mineral dust samples, and on individual mineral and clay mineral components, Phys. Chem. Chem. Phys., 3, 2474-2482, 2001 b.

Hatakeyama, S., Tanonaka, T., Weng, J., Bandow, H., Takagi, H., and Akimoto, H.: Ozone-cyclohexene reaction in air: quantitative analyses of particulate products and the reaction mechanism, Environ. Sci. Technol., 19, 935-942, 1985.

Ho, K. F., Lee, S. C., Cao, J. J., Kawamura, K., Watanabe, T., Cheng, Y., and Chow, J. C.: Dicarboxylic acids, ketocarboxylic acids and dicarbonyls in the urban roadside area of Hong Kong, Atmos. Environ., 40, 3030-3040, 2006.

Ho, K. F., Huang, R.-J., Kawamura, K., Tachibana, E., Lee, S. C., Ho, S. S. H., Zhu, T., and Tian, L.: Dicarboxylic acids, ketocarboxylic acids, $\alpha$-dicarbonyls, fatty acids and benzoic acid in $\mathrm{PM}_{2.5}$ aerosol collected during CAREBeijing-2007: an effect of traffic restriction on air quality, Atmos. Chem. Phys., 15, 31113123, doi:10.5194/acp-15-3111-2015, 2015.

Huang, H. -M., Katrib, Y., and Martin, S. C.: Products and mechanisms of the reaction of oleic acid with ozone and nitrate radical, J. Phys. Chem. A, 109, 4517-4530, 2005.

Huang, X. F., Yu, J. Z., He, L. Y., and Yuan, Z. B.: Watersoluble organic carbon and oxalate in aerosols at a coastal urban site in China: Size distribution characteristics, sources, and formation mechanisms, J. Geophys. Res., 111, D22212, doi:10.1029/2006JD007408, 2006.

Irei, S., Takami, A., Hayashi, M., Sadanaga, Y., Hara, K., Kaneyasu, N., Sato, K., Arakaki, T., Hatakeyama, S., Bandow, H., Hikida, T., and Shimono, A.: Transboundary secondary organic aerosol in western Japan indicated by the $\delta^{13} \mathrm{C}$ of water-soluble organic carbon and the $m / z 44$ signal in organic aerosol mass spectra, Environ. Sci. Technol., 48, 6273-6281, 2014.

Jacobson, M. Z.: Atmospheric Pollution: History, Science, and Regulation. Cambridge University Press, United Kingdom, ISBN10: 0-521-81171-6, 2002.

Jacobson, M. C., Hansson, H. C., Noone, K. J., and Charlson, R. J.: Organic atmospheric aerosols: Review and state of science, Rev. Geophys., 38, 267-294, 2000.

Jefferson, A., Tanner, D. J., Eisele, F. L., Davis, D. D., Chen, G., Creawford, J., Huey, J. W., Torres, A. L., and Berresheim, H.: $\mathrm{OH}$ photochemistry and methane sulfonic acid formation in the coastal Antarctic boundary layer, J. Geophys. Res., 103, 16471656, 1998.

Japan Meteorological Agency, Tokyo, Japan: Meteorological data of Okinawa, available at: http://www.jma.go.jp, last access: 5 January 2015.

Kalberer, M., Yu, J., Cocker, D. R., Flagan, R. C., and Seinfeld, J. H.: Aerosol formation in the cyclohexene-ozone system, Environ. Sci. Technol., 34, 4894-4901, 2000.

Kanakidou, M., Seinfeld, J. H., Pandis, S. N., Barnes, I., Dentener, F. J., Facchini, M. C., Van Dingenen, R., Ervens, B., Nenes, A., Nielsen, C. J., Swietlicki, E., Putaud, J. P., Balkanski, Y., Fuzzi, S., Horth, J., Moortgat, G. K., Winterhalter, R., Myhre, C. E. L., Tsigaridis, K., Vignati, E., Stephanou, E. G., and Wilson, 
J.: Organic aerosol and global climate modelling: a review, Atmos. Chem. Phys., 5, 1053-1123, doi:10.5194/acp-5-1053-2005, 2005.

Kaufman, Y. J. and Fraser, R. S.: The effect of smoke particles on clouds and climate forcing, Science, 277, 1636-1639, 1997.

Kawamura, K.: Identification of $\mathrm{C}_{2}-\mathrm{C}_{10} \omega$-oxocarboxylic acids, pyruvic acid, and $\mathrm{C}_{2}-\mathrm{C}_{3} \alpha$-dicarbonyls in wet precipitation and aerosol samples by capillary GC and GC/MS, Anal. Chem., 65, 3505-3511, 1993.

Kawamura, K. and Bikkina, S.: A review of dicarboxylic acids and related compounds in atmospheric aerosols: Molecular distributions, sources and transformation, Atmos. Res., 170, 140-160, 2016.

Kawamura, K. and Gagosian, R. B.: Implications of $\omega$ oxocarboxylic acids in the remote marine atmosphere for photooxidation of unsaturated fatty acids, Nature, 325, 330-332, 1987.

Kawamura, K. and Ikushima, K.: Seasonal changes in the distribution of dicarboxylic acids in the urban atmosphere, Environ. Sci. Technol., 27, 2227-2235, 1993.

Kawamura, K. and Kaplan, I. R.: Motor Exhaust Emissions as a Primary Source for Dicarboxylic-Acids in Los-Angeles Ambient Air, Environ. Sci. Technol., 21, 105-110, 1987.

Kawamura, K. and Sakaguchi, F.: Molecular distributions of water soluble dicarboxylic acids in marine aerosols over the Pacific Ocean including tropics, J. Geophys. Res., 104, 3501-3509, 1999.

Kawamura, K. and Usukura, K.: Distributions of low molecular weight dicarboxylic acids in the North Pacific aerosol samples, J. Oceanogr., 49, 271-283, 1993.

Kawamura, K. and Yasui, O.: Diurnal changes in the distribution of dicarboxylic acids, ketocarboxylic acids and dicarbonyls in the urban Tokyo atmosphere, Atmos. Environ., 39, 1945-1960, 2005.

Kawamura, K., Ng, L., and Kaplan, I. R., Determination of organic acids $\left(\mathrm{C}_{1}-\mathrm{C}_{10}\right)$ in the atmosphere, motor-exhausts and engine oils, Environ. Sci. Technol., 19, 1082-1086, 1985.

Kawamura, K., Kasukabe, H., and Barrie, L. A.: Source and reaction pathways of dicarboxylic acids, ketoacids and dicarbonyls in arctic aerosols: One year of observations, Atmos. Environ., 30, 1709-1722, 1996.

Kawamura, K., Imai, Y., and Barrie, L. A.: Photochemical production and loss of organic acids in high Arctic aerosols during longrange transport and polar sunrise ozone depletion events, Atmos. Environ., 39, 599-614, 2005.

Kawamura, K., Narukawa, M., Li, S. M., and Barrie, L. A.: Size distributions of dicarboxylic acids and inorganic ions in atmospheric aerosols collected during polar sunrise in the Canadian high Arctic, J. Geophys. Res., 112, D10307, doi:10.1029/2006JD008244, 2007.

Kawamura, K. and Pavuluri, C. M.: New Directions: Need for better understanding of plastic waste burning as inferred from high abundance of terephthalic acid in South Asian aerosols, Atmos. Environ., 44, 5320-5321, 2011.

Kerminen, V.-M., Pakkanen, T. A., and Hillamo, R. E.: Interactions between inorganic trace gases and supermicrometer particles at a coastal site, Atmos. Environ., 31, 2753-2765, 1997a.

Kerminen, V.-M., Aurela, M., Hillamo, R. E., and Virkkula, A.: Formation of particualte MSA: deductions from size distribu- tion measurements in the Finnish Arctic, Tellus, 49b, 159-171, 1997b.

Kleeman, M. J. and Cass, G. R.: Effect of emissions control strategies on the size and composition distribution of urban particulate air pollution, Environ. Sci. Technol., 33, 177-189, 1999.

Kouyoumdjian, H. and Saliba, N. A.: Mass concentration and ion composition of coarse and fine particles in an urban area in Beirut: effect of calcium carbonate on the absorption of nitric and sulfuric acids and the depletion of chloride, Atmos. Chem. Phys., 6, 1865-1877, doi:10.5194/acp-6-1865-2006, 2006.

Kumar, A., Sarin, M. M., and Sudheer, A. K.: Mineral and anthropogenic aerosols in Arabian Sea-atmospheric boundary layer: Sources and spatial variability, Atmos. Environ., 42, 5169-5181, 2008.

Kundu, S., Kawamura, K., Andreae, T. W., Hoffer, A., and Andreae, M. O.: Molecular distributions of dicarboxylic acids, ketocarboxylic acids and a-dicarbonyls in biomass burning aerosols: implications for photochemical production and degradation in smoke layers, Atmos. Chem. Phys., 10, 2209-2225, doi:10.5194/acp-10-2209-2010, 2010.

Kunwar, B. and Kawamura, K.: Seasonal distribution and sources of low molecular weight dicarboxylic acids, $\omega$-oxocarboxylic acids, pyruvic acid, $\alpha$-dicarbonyls and fatty acids in ambient aerosols from subtropical Okinawa in the western Pacific Rim, Environ. Chem., 11, 673-689, 2014.

Legrand, M., Preunkert, S., Oliveira, T., Pio, C. A., Hammer, S., Gelencser, A., Kasper-Giebl, A., and Laj, P.: Origin of $\mathrm{C}_{2}-\mathrm{C}_{5}$ dicarboxylic acids in the European atmosphere inferred from yearround aerosol study conducted at a west-east transect, J. Geophys. Res., 112, D23S07, doi:10.1029/2006JD008019, 2007.

Lim, H. J., Carlton, A. G., and Turpin, B. J.: Isoprene forms secondary organic aerosol through cloud processing: Model simulations, Environ. Sci. Technol., 39, 4441-4446, 2005.

Lim, Y. B., Tan, Y., Perri, M. J., Seitzinger, S. P., and Turpin, B. J.: Aqueous chemistry and its role in secondary organic aerosol (SOA) formation, Atmos. Chem. Phys., 10, 1052110539, doi:10.5194/acp-10-10521-2010, 2010.

Liu, S. Z., Tao, S., Liu, W. X., Liu, Y. N., Dou, H., Zhao, J. Y., Wang, L. G., Wang, J. F., Tian, Z. F., and Gao, Y.: Atmospheric polycyclic aromatic hydrocarbons in north China: A winter-time study, Environ. Sci. Technol., 41, 8256-8261, 2007.

Matsunaga, S., Kawamura, K., Nakatsuka, T., and Ohkouchi, N.: Preliminary study on laboratory photochemical formation of low molecular weight dicarboxylic acids from unsaturated fatty acid (oleic acid), Res. Org. Geochem., 14, 19-25, 1999.

Meinardi, S., Simpson, I. J., Blake, N. J., Blake, D. R., and Rowland, E. S.: Dimethyl disulfide (DMDS) and dimethyl sulfide (DMS) emissions from biomass burning in Australia, Geophys. Res. Lett., 30, 1454, doi:10.1029/2003GL016967, 2003.

Miyazaki, Y., Kawamura, K., and Sawano, M.: Size distributions and chemical characterization of water-soluble organic aerosols over the western North Pacific in summer, J. Geophys. Res., 115, D23210, doi:10.1029/2010JD014439, 2010.

Miyazaki, Y., Kawamura, K., Jung, J., Furutani, H., and Uematsu, M.: Latitudinal distributions of organic nitrogen and organic carbon in marine aerosols over the western North Pacific, Atmos. Chem. Phys., 11, 3037-3049, doi:10.5194/acp-11-3037-2011, 2011. 
Mkoma, S. L., Kawamura, K., and Fu, P. Q.: Contributions of biomass/biofuel burning to organic aerosols and particulate matter in Tanzania, East Africa, based on analyses of ionic species, organic and elemental carbon, levoglucosan and mannosan, Atmos. Chem. Phys., 13, 10325-10338, doi:10.5194/acp-1310325-2013, 2013.

Mochida, M., Umemoto, N., Kawamura, K., and Uematsu, M.: Bimodal size distribution of $\mathrm{C}_{2}-\mathrm{C}_{4}$ dicarboxylic acids in the marine aerosols, Geophys. Res. Lett., 30, 1672, doi:10.1029/2003GL017451, 2003a.

Mochida, M., Kawabata, A., Kawamura, K., Hatsushika, H., and Yamazaki, K.: Seasonal variation and origins of dicarboxylic acids in marine atmosphere over the western North Pacific, J. Geophys. Res., 108, 4193, doi:10.1029/2002JD002355, $2003 \mathrm{~b}$.

Mochida, M., Umemoto, N., Kawamura, K., Lim, H. J., and Turpin, B. J.: Bimodal size distributions of various organic acids and fatty acids in the marine atmosphere: Influence of anthropogenic aerosols, Asian dusts, and sea spray off the coast of East Asia, J. Geophys. Res., 112, D15209, doi:10.1029/2006JD007773, 2007.

Myriokefalitakis, S., Tsigaridis, K., Mihalopoulos, N., Sciare, J., Nenes, A., Kawamura, K., Segers, A., and Kanakidou, M.: Incloud oxalate formation in the global troposphere: a 3-D modeling study, Atmos. Chem. Phys., 11, 5761-5782, doi:10.5194/acp11-5761-2011, 2011.

Nenes, A., Pandis, S. N., and Pilinis, C.: ISORROPIA: A new thermodynamic equilibrium model for multiphase multicomponent inorganic aerosols, Aquat. Geochem., 4, 123-152, 1998.

Pakkanen, T. A., Loukkola, K., Korhonen, C. H., Aurela, M., Makela, T., Hillamo, R. E., Aarnio, P., Koskentalo, T., Kousa, A., and Maenhaut, W.: Sources and chemical composition of atmospheric fine and coarse particles in the Helsinki area, Atmos. Environ., 35, 5381-5391, 2001.

Pavuluri, C. M., Kawamura, K., Mihalopoulos, N., and Swaminathan, T.: Laboratory photochemical processing of aqueous aerosols: formation and degradation of dicarboxylic acids, oxocarboxylic acids and a-dicarbonyls, Atmos. Chem. Phys., 15, 7999-8012, doi:10.5194/acp-15-7999-2015, 2015.

Pope, C. A. and Dockery, D. W.: Health effects of fine particulate air pollution: Lines that connect, J. Air Waste Manage., 56, 709742, 2006

Pradeep Kumar, P., Broekhuizen, K., and Abbatt, J. P. D.: Organic acids as cloud condensation nuclei: Laboratory studies of highly soluble and insoluble species, Atmos. Chem. Phys., 3, 509-520, doi:10.5194/acp-3-509-2003, 2003.

Quinn, P. K., Covert, D. S., Bates, T. S., Kapustin, V. N., Ramseybell, D. C., and Mcinnes, L. M.: Dimethylsulfide cloud condensation nuclei climate system - relevant size-resolved measurements of the chemical and physical-properties of atmospheric aerosolparticles, J. Geophys. Res., 98, 10411-10427, 1993.

Ramanathan, V., Crutzen, P. J., Kiehl, J. T., and Rosenfeld, D.: Atmosphere - Aerosols, climate, and the hydrological cycle, Science, 294, 2119-2124, 2001.

Schauer, J. J., Rogge, W. F., Hildemann, L. M., Mazurek, M. A., and Cass, G. R.: Source apportionment of airborne particualte matter using organic compounds as tracers, Atmos. Environ., 30, 3837-3855, 1996.

Seinfeld, J. H. and Pandis, S. N.: Atmospheric Chemistry and Physics, John Wiley \& Sons, New York, ISBN-13: 978-0-47117815-6, 1998.
Seinfeld, J. H. and Pandis, S. N.: Atmospheric chemistry and physics: From air pollution to climate change, $2^{\text {nd }}$ edition, J. Wiley, New York, ISBN-13: 978-0-471-72018-8, 2006.

Seinfeld, J. H. and Pankow, J. F.: Organic atmospheric particulate material, Annu. Rev. Phys. Chem., 54, 121-140, 2003.

Sempéré, R. and Kawamura, K.: Trans-hemispheric contribution of $\mathrm{C}_{2}-\mathrm{C}_{10} \alpha, \omega$-dicarboxylic acids, and related polar compounds to water-soluble organic carbon in the western Pacific aerosols in relation to photochemical oxidation reactions, Glob. Biogeochem. Cycle, 17, 1069, doi:10.1029/2002GB001980, 2003.

Shimada, K., Shimida, M., Takami, A., Hasegawa, S., Akihiro, F., Arakaki, T., Izumi, W., and Hatakeyama, S.: Mode and place of origin of carbonaceous aerosols transported from East Asia to Cape Hedo, Okinawa, Japan, Aerosol Air. Qual. Res., 15, 799813, 2015.

Simoneit, B. R. T., Medeiros, P. M., and Didyk, B. M.: Combustion products of plastics as indicators for refuse burning in the atmosphere, Environ. Sci. Technol., 39, 6961-6970, 2005.

Speer, R. E., Edney, E. O., and Kleindienst, T. E.: Impact of organic compounds on the concentrations of liquid water in ambient $\mathrm{PM}_{2.5}$, J. Aerosol Sci., 34, 63-77, 2003.

Takami, A., Miyoshi, T., Shimono, A., Kaneyasu, N., Kato, S., Kajii, Y., and Hatakeyama, S.: Transport of anthropogenic aerosols from Asia and subsequent chemical transformation, J. Geophys. Res., 112, D22S31, doi:10.1029/2006jd008120, 2007.

Takiguchi, Y., Takami, A., Sadanaga, Y., Lun, X. X., Shimizu, A., Matsui, I., Sugimoto, N., Wang, W., Bandow, H., and Hatakeyama, S.: Transport and transformation of total reactive nitrogen over the East China Sea, J. Geophys. Res., 113, D10306, doi:10.1029/2007jd009462, 2008.

Tao, J., Zhang, L., Engling, G., Zhang, R., Yang, T., Cao, J., Zhu, C., Wang, Q., and Luo, L.: Chemical composition of $\mathrm{PM}_{2.5}$ in an urban environment in Chengdu, China: Importance of springtime dust storms and biomass burning, Atmos. Res., 122, 270-283, 2013.

Tao, S., Wang, Y., Wu, S. M., Liu, S. Z., Dou, H., Liu, Y. N., Lang, C., Hu, F., and Xing, B. S.: Vertical distribution of polycyclic aromatic hydrocarbons in atmospheric boundary layer of Beijing in winter, Atmos. Environ., 41, 9594-9602, 2007.

Tedetti, M., Kawamura, K., Narukawa, M., Joux, F., Charriere, B., and Sempéré, R.: Hydroxyl radical-induced photochemical formation of dicarboxylic acids from unsaturated fatty acid (oleic acid) in aqueous solution, J. Photochem. Photobiol A., 188, 135139, 2007.

Tsai, Y. I. and Chen, C. L.: Characterization of Asian dust storm and non-Asian dust storm $\mathrm{PM}_{2.5}$ aerosol in southern Taiwan, Atmos. Environ., 40, 4734-4750, 2006.

Turpin, B. J. and Lim, H. J.: Species contributions to $\mathrm{PM}_{2.5}$ mass concentrations: Revisiting common assumptions for estimating organic mass, Aerosol. Sci. Tech., 35, 602-610, 2001.

Volkamer, R., Platt, U., and Wirtz, K.: Primary and secondary glyoxal formation from aromatics: Experimental evidence for the bicycloalkyl-radical pathway from benzene, toluene, and pxylene, J. Phys. Chem. A, 105, 7865-7874, 2001.

Wang, G. H., Kawamura, K., Xie, M. J., Hu, S. Y., Li, J. J., Zhou, B. H., Cao, J. J., and An, Z. S.: Selected water-soluble organic compounds found in size-resolved aerosols collected from urban, mountain and marine atmospheres over East Asia, Tellus, 63, 371-381, 2011. 
Wang, G. H., Zhou, B. H., Cheng, C. L., Cao, J. J., Li, J. J., Meng, J. J., Tao, J., Zhang, R. J., and Fu, P. Q.: Impact of Gobi desert dust on aerosol chemistry of Xi' an, inland China during spring 2009: differences in composition and size distribution between the urban ground surface and the mountain atmosphere, Atmos. Chem. Phys., 13, 819-835, doi:10.5194/acp-13-819-2013, 2013.

Wang, H., Kawamura, K., and Shooter, D.: Carbonaceous and ionic components in wintertime atmospheric aerosols from two New Zealand cities: Implication for solid fuel combustion, Atmos. Environ., 39, 5865-5875, 2005.

Wang, Y., Zhuang, G. S., Sun, Y., and An, Z. S.: Water-soluble part of the aerosol in the dust storm season - evidence of the mixing between mineral and pollution aerosols, Atmos. Environ., 39, 7020-7029, 2005.
Warneck, P.: In-cloud chemistry opens pathway to the formation of oxalic acid in the marine atmosphere, Atmos. Environ., 37, 2423-2427, 2003.

Yamasoe, M. A., Artaxo, P., Miguel, A. H., and Allen, A. G.: Chemical composition of aerosol particles from direct emissions of vegetation fires in the Amazon Basin: water-soluble species and trace elements, Atmos. Environ., 34, 1641-1653, 2000.

Ziemann, P. J.: Aerosol products, mechanisms, and kinetics of heterogeneous reactions with oleic acid in pure and mixed particles, Faraday Discuss., 130, 469-490, 2005.

Zimmermann, J. and Poppe, D.: A supplement for the RADM2 chemical mechanism: The photooxidation of isoprene, Atmos. Environ., 30, 1255-1269, 1996. 